University of Maine School of Law

University of Maine School of Law Digital Commons

Faculty Publications

Faculty Scholarship

$1-21-2019$

\title{
The brave new world of energy and natural resources development
}

Donald N. Zillman

University of Maine School of Law, donald.zillman@maine.edu

Follow this and additional works at: https://digitalcommons.mainelaw.maine.edu/facultypublications

Part of the Energy and Utilities Law Commons, and the Environmental Law Commons

\section{Recommended Citation}

37 J. Energy \& Nat. Resources L. 3

This Article is brought to you for free and open access by the Faculty Scholarship at University of Maine School of Law Digital Commons. It has been accepted for inclusion in Faculty Publications by an authorized administrator of University of Maine School of Law Digital Commons. For more information, please contact mdecrow@maine.edu. 


\section{Journal of Energy \& Natural Resources Law}

\section{The brave new world of energy and natural resources development}

\section{Donald N Zillman \& Don C Smith}

To cite this article: Donald N Zillman \& Don C Smith (2019): The brave new world of energy and natural resources development, Journal of Energy \& Natural Resources Law, DOI: 10.1080/02646811.2019.1557394

To link to this article: https://doi.org/10.1080/02646811.2019.1557394

曲 Published online: 21 Jan 2019.

Submit your article to this journal 준

View Crossmark data $₫$ 


\section{The brave new world of energy and natural resources development}

Donald N Zillman, is the Edward S Godfrey Professor of Law at the University of Maine School of Law. He has taught and written about energy law for more than 40 years. Formerly President of the University of Maine at Presque Isle, he most recently served as Lead Editor on the book Innovation in Energy Law and Technology, which was written by the Academic Advisory Group $(A A G)$ of the IBA's Section on Energy, Environment, Natural Resources and Infrastructure Law. Email: donald.zillman@maine.edu; Don C Smith, is an Associate Professor of the Practice of Law at the University of Denver Sturm College of Law. He is Editor of the Journal of Energy \& Natural Resources Law.Email: dcsmith@law.du.edu

(Received 10 November 2018; final version received 1 December 2018)

The world of energy and natural resources development has changed a great deal over the past 30 months, perhaps more so than in the preceding 30 years. Beginning with the June 2016 vote in the United Kingdom to leave the European Union and continuing through today, there are global signs of increasing emphasis on protecting national sovereignty and less on world efforts to address major environmental and energy issues. Admittedly, the United Nations-based effort to reduce greenhouse gas emissions continues to move forward. However, more than a few nations are hinting that they may not live up to their commitments agreed in the form of the Paris Climate Agreement. There is no clearer example than the United States, where since January 2017 President Donald Trump has taken steps to deconstruct the US federal government's role in reducing greenhouse gas emissions. This article current as of 1 December - takes account of what is happening around the world in terms of major political changes that will affect the world's ability to address environmental challenges. Special attention is devoted to what is happening in the US under the Trump administration. The final part of the article analyses the impact of the November 2018 midterm election that will see Democrats take charge of the US House of Representatives in January 2019 and the Trump administration environmental, energy and natural resources agenda.

Keywords: Affordable Clean Energy (ACE) proposed rule; Paris Climate Agreement; US House of Representatives; US Senate; 2018 US midterm election results

\section{Introduction}

Since the late 1970s, the International Bar Association's Section on Energy, Environment, Natural Resources and Infrastructure Law (IBA SEERIL) has supported a creative collaboration between the entire Section and its academic members who comprise the Academic Advisory Group (AAG). Beginning in 2000, a major responsibility of the AAG became the research and writing of books that study pathbreaking developments in energy, environmental and natural resources law. In 2002, the IBA SEERIL and the AAG began a productive collaboration with Oxford University Press (OUP) to publish the books to coincide with the Section's biennial meetings held around the world.

The authors of this article had the opportunity and challenge of working on the 2017-2018 book, Innovation in Energy Law and Technology: Dynamic Solutions for 
Energy Transitions. ${ }^{1}$ Professor Zillman served as the Lead Editor and helped write the Introduction and Conclusion to the book along with co-editors Professors Martha Roggenkamp, LeRoy Paddock and Lee Godden. ${ }^{2}$ Professor Smith served as a chapter author of the book in addition to his duties as Editor of the IBA's Journal of Energy \& Natural Resources Law. ${ }^{3}$

The book proved to be a fascinating collaborative project. Thirty-seven authors from 22 nations on six continents contributed chapters to the book. Selection of the book's topic began shortly before the March 2016 biennial meeting of the IBA SEERIL in New York City. That meeting came shortly after the historic Paris Climate Agreement had been reached in December 2015. ${ }^{4}$ The support of both China and the United States for the Paris Agreement appeared to signal universal agreement on the need for aggressive action to control climate change. The theme of innovation in energy law and technology was stimulated by that apparently path-breaking endorsement of strong international collaboration. AAG members at the New York meeting endorsed the innovation topic with a strong focus on climate change.

The next priorities for the AAG were the assignment of chapter topics to AAG members, the selection of editors for the book and the submission of the publication proposal to OUP. The four editors completed a prospectus for the book in late summer 2016 and submitted it to OUP. That prospectus reflected the uncertainty over the exact scope of the topic that had been approved in New York City. It also reflected the unexpected United Kingdom vote to leave the European Union (Brexit) $^{5}$ in June 2016 and the nomination of Donald J Trump, a serious sceptic about the Paris Agreement and climate science generally, as the Republican Party nominee for President in the November 2016 American election.

Following its normal practice, OUP submitted the book prospectus to three anonymous reviewers. Their comments expressed concern about possible overemphasis on climate change in a book on energy innovation and the need for sufficient discussion of academic scholarship in the fields of technology and social science as it related to innovation.

The comments from the outside reviewers and OUP were valuable in clarifying and improving the final book, but it left the editors facing a tight timetable that required presentation of a final manuscript to OUP in autumn 2017 to allow publication shortly before the SEERIL biennial meeting in Lisbon in April 2018.

Meanwhile, in the world at large, conditions continued to change. The unexpected election of Donald Trump set the stage for the most significant change in American energy and environmental policy in history. The Brexit vote was followed by further

1 Donald Zillman and others (eds), Innovation in Energy Law and Technology (Oxford University Press 2018) (hereinafter Energy Innovation).

2 'Introduction' in Energy Innovation (n 1) 1; 'Conclusion' in Energy Innovation (n 1) 412.

3 Don Smith, 'Unconventional Gas Development 2.0: Reducing the "Environmental Footprint" Through New Technologies' in Energy Innovation (n 1) 224.

4 Paris Climate Agreement https://unfccc.int/process-and-meetings/the-paris-agreement/the-parisagreement accessed 4 December 2018.

5 For current reflection on the implementation (or non-implementation) of Brexit, see The Economist (24 November 2018) 19 and The Economist (17 November 2018) 59 and 61. 
'nationalist' and 'populist' developments around the world that were sceptical about international institutions and fearful of the impact of climate change legislation on domestic economies.

The editors' modified proposal recognised that innovation in both technology and law in energy involved more than just climate change. Under Professor Godden's leadership we also crafted an Introduction that blended our legal scholarship with general social sciences scholarship on innovation. The revised proposal was approved by OUP. Our authors were then briefed on the expectations for their chapters. Authors and editors moved promptly to complete their work. Our work on publication details often involved email chains running from Portland, Maine and Washington, DC in the US to Melbourne, to Groningen in the Netherlands, to our editors in Oxford and to our printers in Chennai, India. Good spirits in all quarters allowed us to meet our deadlines and have the handsome Innovation in Energy Law and Technology volume ready for distribution in April $2018 .^{6}$

\section{The book}

The concluding chapter of Energy Innovation provided a chapter-by-chapter review of the book. We do not repeat that here. However, we recognise that many of our 37 authors did not have access to each other's chapters to know whether their observations matched those of their fellow authors and those of contributors to the Journal of Energy \& Natural Resources Law too.

The 21 chapters of Energy Innovation study numerous technological and legal innovations in energy. Many of the technological innovations offer the ability to reduce the generation and release of carbon gases with their impact on climate change. Other technological innovations have enhanced the use of fossil fuels. Notable in the latter category are the advances in horizontal drilling and hydraulic fracturing that have greatly expanded the accessible supplies of petroleum and natural gas in nations around the world. ${ }^{7}$ Other technological developments considered by the authors include offshore and small-scale nuclear electric generating facilities, ${ }^{8}$ use of hydrogen for both transportation and electric generation, ${ }^{9}$ 'smart' energy technologies, ${ }^{10}$

6 The timetable was designed to provide a copy of the newly published book to each of the several hundred registrants for the biennial SEERIL meeting.

7 See Smith (n 3); Hugo Meyer van den Berg and Hanri Mostert, 'Challenges to Regulating Hydraulic Fracturing in South Africa' in Energy Innovation (n 1) 244.

8 See Catherine Redgwell and Efthymios Papastavridis, 'International Regulatory Challenges of New Developments in Offshore Nuclear Technologies: Transportable Nuclear Power Plants' in Energy Innovation (n 1) 103; Daniel F Stenger, Amy C Roma and Sachin Desai, 'Innovation in Nuclear Power: How We Got Here and How to Move Forward' in Energy Innovation (n 1) 117.

9 Ruven Fleming and Joshua Fershee, 'The "Hydrogen Economy" in the United States and the European Union: Regulating Innovation to Combat Climate Change' in Energy Innovation (n 1) 137.

10 Anita Rønne, 'Smart Cities and Smart Regulation: Accelerating Innovative Renewable Technologies in Energy Systems to Mitigate Climate Change' in Energy Innovation (n 1) 55; José Juan González Márquez and Margarita González Brambila, 'Regulation of Electricity Storage, Intelligent Grids, and Clean Energies in an Open Market in Mexico' in Energy Innovation (n 1) 172; Lee Godden and Anne Kallies, 'Smart Infrastructure: Innovative Energy Technology, Climate Mitigation, and Consumer Protection in Australia and Germany' in Energy Innovation (n 1) 391. 
bio-methane use, combined heat and power technologies ${ }^{11}$ and distributed energy resources. $^{12}$

Numerous chapters took a national or regional look at innovative technologies. The $\mathrm{EU}^{13}$ and the Middle East ${ }^{14}$ are the subject of regional studies. Other chapters consider national innovations in China, ${ }^{15}$ Russia, Canada, ${ }^{16}$ Mexico, Colombia, ${ }^{17}$ the Republic of South Africa, Brazil ${ }^{18}$ and the American State of Colorado ${ }^{19}$ and the Canadian Province of Alberta. ${ }^{20}$

The chapter authors agreed that technological innovation often leads legal innovation. But legal innovation can stimulate technological innovation, too. Several chapters consider situations in which existing law (international legal standards, national constitutional provisions, statutes, regulations, judicial decisions) had been created with no appreciation of the impact of subsequent technological innovations. Developments in hydraulic fracturing are illustrative. So too are innovative uses of various forms of gas and hydrogen. ${ }^{21}$ Distributed small-scale production of electricity fits awkwardly into existing legal structures that assume large-scale production, transmission and distribution of electricity by single monopolist utilities. $^{22}$

When the existing law was not written with new technologies in mind, lawyers are initially forced to see whether they can interpret the existing laws to reach a result that endorses the new technology. The more effective solution is for the appropriate lawmaking body to rewrite the existing law with the new technology in mind. Making new law may be easy in some regulatory contexts, harder when statutory change is needed, harder still if constitutional revision is required, and hardest of all if multinational rules of international law need changing.

11 Anatole Boute and Sergey Seliverstov, 'A Tortuous Path to Efficiency and Innovation in Heat Supply: Lessons from the Russian Experience with District Heating' in Energy Innovation (n 1) 209.

12 LeRoy Paddock and Karyan San Martano, 'Energy Supply Planning in a Distributed Energy Resources World' in Energy Innovation (n 1) 371.

13 Iñigo del Guayo Castiella, 'Support for Renewable Energies and the Creation of a Truly Competitive Electricity Market: The Case of the European Union' in Energy Innovation (n 1) 305.

14 Damilola S Olawuyi, 'Advancing Innovations in Renewable Energy Technologies as Alternatives to Fossil Fuel Use in the Middle East: Trends and Limitations, and Ways Forward' in Energy Innovation (n 1) 354.

15 Wang Mingyuan and Gao Lailong, 'Technological Innovation and Reform of the Chinese Electric Power System' in Energy Innovation (n 1) 321.

16 Alastair R Lucas and Chidinma B Thompson, 'Transition to a Low-Carbon Energy Economy: The Legal Agenda' in Energy Innovation (n 1) 38; Nigel Bankes, 'Transitioning to a Lower Carbon Future: Phasing out Coal and Promoting Renewables in Alberta's Electricity Sector' in Energy Innovation (n 1) 287.

17 Milton Fernando Montoya, 'The Coal Dilemma: Innovations in Thermal Production in Colombia as a Means to Address the Challenges of Energy Security and Climate Change' in Energy Innovation (n 1) 193.

18 Yanko Marcius de Alencar Xavier and Anderson Souza da Silva Lanzillo, 'Financing Renewable Energy in Brazil: Challenges of Climate Change and Innovation’ in Energy Innovation (n 1) 337.

19 Smith (n 3).

20 See, eg, Bankes (n 16).

21 Fleming and Fershee (n 9); Martha Roggenkamp, Jacob Sandholt and Daisy G Tempelman, 'Innovation in the EU Gas Sector: Injection of Biomethane into the Natural Gas System' in Energy Innovation (n 1) 262.

22 Paddock and San Martano (n 12). 
The studies reveal that in modern times technological innovation and legal innovation often proceed in tandem. Serious investment in the development of a technological innovation needs coordination among the scientists and engineers who have developed the technology, private investors and existing agencies of government acting as financial supporters, regulators and often owners of the new technology. Widespread support among these communities provides a powerful stimulus to the writing of new statutes or regulations that encourage the development of the technology. Often the new laws take innovative approaches to law-making. In summary, technological innovation both leads and is led by legal innovation.

The chapters also reveal the division of legal responsibility among levels of government. The advance of new energy technologies has been influenced by local (cities, counties, towns, special purpose districts), regional (states, provinces, länder), national, multinational (notably the EU) and international law. The attitudes of these bodies and their laws may vary and sometimes conflict. For example, an innovative technology for developing an underground mineral resource may persuade a local community located above the resource that extraction provides a source of wealth for some local citizens, an attractive source of new employment, a powerful addition to local tax revenues and an overall stimulant to community growth. Other community residents may fear the environmental pollution, harm to existing businesses (eg, recreation and tourism) and only a limited return of wealth to the local population. Larger geographic units of government may weigh the pluses and minuses differently.

The chapters also highlighted the sharp divides between rural and urban populations over innovation issues. A major development over the last two centuries has been the movement of people around the world from the country to the city. A century ago this movement would be portrayed as a shift from rural, agricultural society to the industrial manufacturing employment of big cities with their higher crime rates, environmental pollution and lack of social cohesion. The individual's choice to move was voluntary but nostalgia often mourned the loss of stable, value-based rural life to secure the higher incomes in the cities.

In recent decades, the positives of urban living have increased as service industries replaced manufacturing industries. Innovation clusters have centred around cities that attract like-minded innovators and provide well-paying jobs, stimulating colleagues and diverse social and cultural opportunities. Young university graduates are particularly drawn to the cities. Many American states and regions now face a decline in small town life. Those attractions also have political impact. In the US city voters typically support the Democratic Party. Rural voters typically support the Republican Party.

The chapters also consider how governments should best manage their exhaustible energy minerals like oil, natural gas and coal. Environmental advocates often urge a 'keep it in the ground' approach to fight the negatives of climate change and other environmental pollution. Business developers (extractive industries, their financial supporters, their governmental advocates) weigh 'today' versus 'tomorrow' decisions. What if today's decision to develop a coal mine or oil or gas reservoir is prohibited from operation a decade from now, well before its potential productive life has ended? Who bears the costs of the 'stranded asset'? From a different perspective, what are the benefits of extracting the exhaustible resources as rapidly as possible and using those revenues now for the benefit of the private sector, governments and society in general? 


\section{Recent developments}

As mentioned, the political climate of the world has changed considerably from late 2015 and the approval of the Paris Agreement to the present day. At the time of its adoption, the Paris Agreement appeared to reflect a worldwide consensus that climate change was a scientifically recognised problem of enormous consequence that had to be addressed soon and collectively by the nations of the world. Different nations would need to address the issues in different ways. But the apparent agreement of President Xi Jinping for China and President Barack Obama for the US, representing the two largest carbon emitters, and strong leadership from the EU appeared to have defined the future.

While assuredly not endorsed throughout the world, 'liberal democratic concepts' were expected to drive the international efforts on climate change. The concepts included legitimately elected governments, governments with power shared among an executive branch, a legislative branch and an independent judiciary with all branches dedicated to the rule of law, a thriving civil society encouraging strong non-governmental organisations, and a vigorous and independent free press.

As we write in December 2018, the world political picture is quite different from that of December 2015. The expectation that international or multinational understandings like the Paris Agreement would be the driver of climate change policy is very much open to question. ${ }^{23}$ So is the assumption that the world's 'liberal democracies' would be the major player in that effort. The election of Donald Trump as US President in November 2016 placed leadership of the American executive branch in the hands of a climate change sceptic, a supporter of bilateral rather than multinational agreements, a vigorous critic of a free press, an advocate of aggressive domestic development of fossil fuels and a strong and self-confessed 'nationalist'. ${ }^{24}$

The decision of the UK to 'Brexit' from the EU has advanced EU scepticism about international organisations and support for authoritarian nationalism. Governments in Turkey, ${ }^{25}$ Poland, Hungary ${ }^{26}$ and Italy $^{27}$ have moved towards autocracy and nationalism. Other EU nations have strong minorities supporting these values. ${ }^{28}$ The media, the courts, independent legislatures and civil society are under attack by those new regimes. ${ }^{29}$ Around the world, such formerly democratic states as the Philippines ${ }^{30}$ and Brazil ${ }^{31}$ have joined those trends. China has endorsed President Xi's 'leadership for life' that harks back to Maoist days. ${ }^{32}$ Vladimir Putin's Russia follows suit. ${ }^{33} \mathrm{We}$ leave it to other authors to elaborate on those nations' evolving policies. We share the US experience of the last three years.

\footnotetext{
Portland Press Herald (from Washington Post, 24 November 2018) A1 (United States government report on climate change).

24 See Portland Press Herald (from Associated Press, 26 September 2018) A2 (President Trump speaking at the United Nations).

25 The Economist (30 June 2018) 47; The Economist (23 June 2018 ) 46.

26 The Economist (19 May 2018) 45.

27 The Economist (19 May 2018) 45; Time (24 September 2018) 35.

28 The Economist (25 August 2018) 39; The Economist (15 September 2018) 59 (Sweden's populist tendencies).

29 The Economist (16 June 2018) 50; but see Time Magazine (23 July 2018) 32.

30 The Economist (30 June 2018) 32.

31 The Economist (27 October 2018) 34; The Economist (3 November 2018) 32.

32 See generally, The Economist (20 October 2018) 25 and 43; The Economist (10 November 2018) 44.

33 See generally, The Economist (13 October 2018) 49 and 50.
} 
The election of Donald Trump was the most stunning political development in American history. Trump entered the 2016 presidential election with no prior experience in government, state or national. He had no prior military experience, a path to power of such American presidents as George Washington, Andrew Jackson, Ulysses Grant, Theodore Roosevelt and Dwight Eisenhower.

To say that Trump had no experience in government is not to say he had no experience with government. His career was as a property developer in New York City where his success was due in part to his skill in working with land use, taxation and government financial subsidy laws and programmes. The bankruptcy laws assisted his exit from his less successful business ventures. That background gave him considerable sophistication in the workings of government. It also shaped his attitudes towards governments - local, state and federal. In particular, it gave him a considerably sceptical view towards government regulation of the private sector.

While Trump's skills as a developer and his enjoyment of self-promotion made him well known in New York, his national visibility took off when he became the host of a nationally televised 'reality show' called The Apprentice. The Apprentice featured young entrepreneurs working for Trump on a creative, entrepreneurial project. They would work among themselves and with Trump collectively to advance the project. Each week's episode would end with Trump dismissing one of the less promising entrepreneurs with the show's catchphrase 'You're fired' until only one winner remained. The young entrepreneurs were attractive (or unattractive) cast members, but the star of the show was Donald Trump, who projected an image of the successful, bold entrepreneur never afraid to 'tell it like it is'.

Future histories will be written trying to identify how Donald Trump moved from businessman/TV star to serious presidential candidate. Trump initially moved into national politics and cast his future with the Republican Party when he questioned President Obama's place of birth in Hawaii. No evidence supported Trump's inferences that Obama did not meet the constitutional requirement that the President be a 'natural born citizen' of the US. But it proved an unsubtle way of highlighting Obama's father's African heritage.

Trump's entry into a crowded Republican primary field in 2015 was initially regarded as a novelty rather than a serious candidacy. However, he did bring the advantage of TV celebrity and his supposed billionaire's bankroll. The latter removed the need of enormous hours spent fundraising for the campaign. The former gave Trump large media access that the dozen plus other Republican candidates coveted. Trump added to his public visibility with bold statements on immigration, government regulation, international relations and the legitimacy of climate change science that made him constantly newsworthy. His overall view of national government was shaped by his promise to 'drain the swamp' of career politicians and other Washington insiders. As a result, Trump shortly stood out in the crowded field of Republican candidates.

The Trump campaign rapidly showed that those advantages could translate into votes in Republican state primary elections. Other candidates dropped out for lack of money and lack of success in gathering votes. The most notable casualty was former Florida Governor Jeb Bush, son of one former President and brother of another. Trump's characterisation of Bush as 'low energy' was clearly intended to highlight Trump's 'high energy' campaign and his promises for change. Trump political rallies energised this base with its core of older, white males who had substantial grievances against the Washington establishment and other elite power structures. 
Trump closed the deal and secured the Republican nomination for President in July of 2016. The stage was then set for a contest of opposites when the Democrats selected Hillary Clinton as their candidate. Clinton's establishment credentials included service as First Lady to her husband Bill Clinton, election and re-election as Senator from New York State and Secretary of State in the first term of Obama's presidency. Clinton arguably survived a rougher primary season than Trump. Democratic socialist Senator Bernie Sanders from the small state of Vermont ran a highly energising campaign for the left wing of the Democratic Party and for younger voters. Sanders portrayed Clinton as an establishment politician in an age that called for bold new policies. What should have been the excitement of the first woman nominated by a major party for President was lost in the passions for Bernie and Trump. Clinton did win more votes in the Democratic primaries and more delegates than Sanders to gain her party's nomination but she entered the final campaign against Trump somewhat wounded.

The campaign from August to early November featured two finalists who genuinely disliked each other and were happy to have their supporters and swing voters know it. Clinton spoke of some part of Trump supporters as 'deplorables'. Trump encouraged chants at his rallies of 'Lock Her Up', urging jailing Clinton for alleged violation of national security laws in her use of a private email account.

Investigations of alleged wrongdoing by both campaigns continued through election day. Some, such as the investigation of Trump campaign collusion with Russian government figures, continue as we write. Trump faced documented allegations of sexual misbehaviour. He responded with claims that Clinton's 'insider' status made voter fraud that would disadvantage Trump highly possible. Trump speculated he might refuse to concede a Clinton election victory.

The Trump campaign did emphasise a number of policy positions that sharply conflicted with those of the Clinton campaign. Several spoke to energy, natural resources and environmental issues. Most notably, Trump doubted the validity of climate change and with that questioned America's commitment to the Paris Agreement. Trump also strongly advocated a policy of aggressive development of fossil fuels. He portrayed underground coal miners as a disadvantaged class who would be revitalised by a Trump administration. Trump further delighted in the expansive development of hydraulic fracturing and horizontal drilling to increase American production of petroleum and natural gas. That would provide America with a major increase in fossil fuel production and the opportunity to become the major exporting nation of fossil fuels. Success in these ventures demanded a roll-back of environmental standards of all kinds. Trump felt that such environmental regulation should be handled at the state, rather than the federal level. State and local governments were generally supportive of extractive industries. Trump also insisted that federal environmental regulations should only be recognised when they had precise statutory authorisation rather than allowing administrative agencies to give broad pro-environmental interpretation to general statutory grants of power to them. Trump made it clear that his appointments of leaders of federal agencies would reflect those priorities.

Candidate Clinton directly opposed most of Trump's approaches to environmental matters. The result was the sharpest candidate disagreement over energy and environmental policy in any presidential campaign in American history.

Prior to election day in November 2016, a strong majority of political experts indicated that a Clinton election was likely but that it would hardly be a landslide and that a soured loser might attempt to contest it. A Trump victory would only be possible if Trump won almost all the states that were expected to be closely contested. 
On election night, Clinton received nearly 3 million votes more than Trump. Much of that margin came from an overwhelming Clinton win in California, America's most populous state. Trump won far more electoral districts and more states than Clinton. The US Constitution provides that presidential elections shall be decided by an electoral college consisting of representatives of each of the 50 states. Close vote margins in half a dozen of those states all broke in Trump's favour and he was chosen as the next American President. ${ }^{34}$

What had America attained in its next President? Speculation ranged widely. But a common theme among political commentators after the election was that Trump, the outraged orator on the campaign trail, would moderate his views once in office. There, he would be guided by advisers expert in the workings of government and alert to the realities of working with a Congress and federal courts who took seriously their leadership roles in a three-part federal government with substantial power in each of the executive, legislative and judicial branches. In the US, the Trump administration and its strong supporters reflect or lead some of the worldwide tendencies mentioned earlier. A few tendencies are illustrative. The US Supreme Court now appears to be sharply divided along political lines. Prospective justices are vetted for their positions on such issues as abortion rights, support for the Second Amendment recognising an individual right 'to bear arms', state control over matters formerly in federal government control and a limited power of executive branch agencies to interpret legislation in areas such as environment and energy. The nomination (and eventual confirmation), in summer 2018, of Court of Appeals Judge Brett Kavanaugh to the Supreme Court resulted in the most divisive confirmation proceeding in the history of the Court, with Republicans almost unanimously supporting the appointment and Democrats almost unanimously opposing it. This divide was present even before allegations of sexual crimes on the part of Judge Kavanaugh in his high school and college years further clouded the decision.

The Congress appears hopelessly deadlocked along party lines and incapable of legislating on many major public policy issues. Its popularity with the American people has on occasion dropped to below ten per cent. ${ }^{35}$ Enormous amounts of an individual legislator's time are spent on fundraising for increasingly expensive election campaigns in which much of the advertising and other public communication is spent attacking the candidate's opponent(s) rather than describing what the candidate has done or would do. Given this partisan gridlock, both Presidents Obama and Trump have often worked around Congress rather than with it.

President Trump has waged an aggressive war against parts of the media for its support of 'fake news'. He describes the media, or portions of it, as 'enemies of the people'. He often appears to urge greater executive control over the news in spite of the Constitutional language forbidding government from 'abridging the freedom ... of the press' in the First Amendment.

The midterm election of 6 November 2018 provided the first nationwide electoral review of President Trump's performance as President. Traditionally, incumbent presidents have seen the opposing party gain seats in the congressional elections that come two years after their election. That was certainly the case with President Obama in

See The Economist (14 July 2018) 21 ('The minority majority').

35 See 'Despise Congress? You're Not Alone' Portland Press Herald (from Tribune News Service, 25 October 2018) A5. 
2010. President Trump, however, was especially active in 2018 in his campaign appearances around the country on behalf of Republican candidates. He was also very clear that their election was a referendum on his performance as President even though his name was not on any ballot.

Pre-election polls and predictions ranged widely. Most felt that only an exceptionally 'blue (Democratic) wave' could switch control of the Senate to the Democrats given the considerable number of vulnerable Democratic seats up for the election (only one-third of the Senate is up for election every two years) and the small number of Republican seats at risk. The House of Representatives was more likely to change from Republican to Democratic control. A change of 23 seats would shift control from Republicans to Democrats. State elections for governor and state legislatures also offered indicators of political sentiments.

After all votes were counted (and some required recounts), the result can be fairly described as mixed. Republicans slightly increased their Senate majority. President Trump's active campaigning helped carry several Republican senators and candidates to victory. The most notable was the narrow re-election of Texas Senator Ted Cruz, one of the most prominent opponents of Trump in the contest for the Republican presidential nomination in 2016. Several Democratic senators lost their seats in states that President Trump won handily in 2016. The House, on the other hand, saw enough Democratic victories to shift control of the body to the opponents of the President. State governor and legislative elections also provided solid gains for the Democrats.

Both parties and President Trump claimed victory. The retention of a Senate majority continues to give the President control over judicial nominations (which only need Senate confirmation of the presidential nomination). A further Supreme Court vacancy in the next two years is quite possible. The control of the Senate also makes it clear that even a House vote to initiate the impeachment of President Trump would be defeated in the Senate where a two-thirds vote would be required to remove the President from office. The shift of House control to the Democrats, however, provides a clear block to legislation that would overturn existing environmental and energy laws. It also provides Democratic leadership in the wide variety of investigations of President Trump's performance in office.

\section{Focus on the Trump administration: energy, environment and natural resources policies - January 2017 to November 2018}

\subsection{Climate change-related}

\subsubsection{In GENERAL}

Attempting to discern President Trump's underlying position about climate change has not always been easy. For example, several years ago he famously tweeted that it was a 'hoax' that was 'created by and for the Chinese'. ${ }^{36}$ He has also disavowed climate change science. ${ }^{37}$

36 Cale Jaffe, 'Melting the Polarization Around Climate Change Politics' (University of Virginia School of Law Public Law and Legal Theory Research Paper Series 2018-31, 24 July 2018) https://papers.ssrn. com/sol3/papers.cfm?abstract_id=3217107 accessed 4 December 2018. See also https://twitter.com/ realdonaldtrump/status/265895292191248385 accessed 4 December 2018. 
On the other hand, just weeks before the 2018 midterm election he said, 'I don't think it's a hoax. I think there is probably a difference. I think something's happening,' adding, 'Something's changing, and it'll change back again. ${ }^{38}$ However, he went on to indicate that he was not sure if climate change was caused by the activities of humans. ${ }^{39}$

When questioned in October 2018 about the recently published Intergovernmental Panel on Climate Change (IPCC) report, ${ }^{40}$ which underscored the urgency of addressing climate change, President Trump questioned the motives of the scientists who authored the document. ${ }^{41}$ 'You'd have to show me the scientists, because they have a very big political agenda,' he said. ${ }^{42}$ His rejection of climate science was made even clearer when he said in the same month that he had a 'natural instinct for science' that allows him to identify the political bias of climate scientists. ${ }^{43}$

Trump was also dismissive of the Fourth National Climate Assessment Report Volume II, ${ }^{44}$ released in late November 2018, which 'presents the starkest warnings to date of the consequences of climate change for the United States'. ${ }^{45}$ The report forecast, among other things, that 'Without substantial and sustained global mitigation and regional adaption efforts, climate change is expected to cause growing losses to American infrastructure and property and impede the rate of economic growth over this century. ${ }^{46}$ The report also predicted enormous economic impacts, noting, 'With continued growth in emissions at historic rates, annual

38 Scott Waldman, 'Did Trump Create a New Talking Point for Skeptics?' (E\&E News Climatewire, 16 October 2018) www.eenews.net/stories/1060102627 accessed 4 December 2018.

39 Ibid.

40 IPCC, 'Global Warming of $1.5^{\circ} \mathrm{C}$ ' (8 October 2018) www.ipcc.ch/report/sr15 accessed 4 December 2018. The report found that unless global warming is kept at or below $1.5 \mathrm{C}$ in relation to pre-industrial levels, billions of people will suffer major natural and/or social dangers. In what can only be described as an 'odd' response to a question about the report's credibility, President Trump replied, 'I want you to look at who drew it. You know, which group drew it,' adding, 'I can give you reports that are fabulous, and I can give you reports that aren't so good.' Mark K Matthews, 'Clashes on Climate Expected after Dems Take House' (E\&E News Climatewire, 7 November 2018) www.eenews.net/climatewire/stories/ 1060105411 accessed 4 December 2018.

41 Manuel Quiñones, 'As Dems Slam Trump's Comments, Most Republicans Shrug' (E\&E News Greenwire, 15 October 2018) www.eenews.net/greenwire/2018/10/15/stories/1060102567 accessed 4 December 2018.

42 Ibid.

43 Rebecca Morin, "Trump Says He Has "Natural Instinct for Science" When It Comes to Climate Change' (Politico, 17 October 2018) www.politico.com/story/2018/10/17/trump-instinct-climatechange-910004 accessed 4 December 2018.

44 'Fourth National Climate Assessment Volume II: Impacts Risks, and Adaptation in the United States' (23 November 2018) https://nca2018.globalchange.gov accessed 4 December 2018. A second report, released on the same day, reported that emissions emanating from federal lands during the period 2005-2014 represented 23.4 per cent of national carbon dioxide emissions. United States Geological Survey, 'Federal Lands Greenhouse Gas Emissions and Sequestration in the United States: Estimates for 2005-2014' 1 https://pubs.usgs.gov/sir/2018/5131/sir20185131.pdf?wpisrc=nl_energy202\& wpmm=1 accessed 4 December 2018.

45 Coral Davenport and Kendra Pierre-Louis, 'U.S. Climate Report Warns of Damaged Environment and Shrinking Economy’ New York Times (23 November 2018) www.nytimes.com/2018/11/23/climate/usclimate-report.html?module=inline accessed 4 December 2018.

46 'Fourth National Climate Assessment Volume II' (n 44) Summary Findings (23 November 2018) 2 https://nca2018.globalchange.gov accessed 4 December 2018. 
losses in some economic sectors are projected to reach hundreds of billions of dollars by the end of the century - more than the current gross domestic product (GDP) of many states. ${ }^{47}$ Taking all of the impacts together, climate change could reduce GDP by up to ten per cent by 2100 , the report concludes. ${ }^{48}$ In response, Trump said, on 26 November 2018, that he had seen and read some of the report, but then went on to say, 'I don't believe it." ${ }^{49}$ Earlier the same month, when shown a copy of the assessment that says humans are causing climate change, Trump said he focuses on reports that dispute its findings. ${ }^{50}$ In this regard, 'Trump repeated a popular talking point among conservatives, acknowledging that humans contribute in some way to global warming without accepting mainstream climate science that says consumption of fossil fuels is responsible for warming the planet. ${ }^{51}$ And Trump has even frequently resorted to invoking snowstorms to question the existence of climate change. ${ }^{52}$

However, what Trump has made absolutely clear is that his administration is not willing to address climate change if it means a loss of American jobs or if it would have an adverse impact on the US economy. ${ }^{53}$ 'I don't want to give up trillions and trillions of dollars,' he has said, adding, 'I don't want to lose millions and millions of jobs. I don't want to be put at a disadvantage. ${ }^{54}$

Bearing all of this in mind, the Trump administration has taken steps to 'dismantle an array of federal efforts to fight global warming ${ }^{55}$ while simultaneously casting himself as a fossil fuel industry ally. ${ }^{56}$ To underscore this, President Trump at a 2017 energy event said, 'You've gone through eight years of hell,' in reference to the two terms of the Obama administration. ${ }^{57}$ Looked at from the perspective of Republican dominance in the White House and the US Congress, climate change has been 'largely ignored' in Trump's first two years in office. ${ }^{58}$

47 'Fourth National Climate Assessment Volume II: Impacts Risks, and Adaptation in the United States' Summary Findings (23 November 2018) 2 https://nca2018.globalchange.gov accessed 4 December 2018.

48 Davenport and Pierre-Louis (n 45).

49 Coral Davenport and Lisa Friedman, 'How Trump Is Ensuring That Greenhouse Gas Emissions Will Rise' New York Times (26 November 2018) www.nytimes.com/2018/11/26/climate/trumpgreenhouse-gas-emissions.html accessed 4 December 2018.

50 Scott Waldman, 'Trump: "People Very Much Dispute" Climate Change' (E\&E News Climatewire, 5 November 2018) www.eenews.net/stories/1060105137 accessed 4 December 2018.

51 Ibid.

52 Jennifer A Dlouhy and Eric Rosen, 'Trump EPA Draws Scorn for Touting Greenhouse-Gas Emissions Cuts (1)’ (Bloomberg Environment \& Energy Report, 17 October 2018).

53 Jennifer A Dlouhy, 'Scientists to Trump: "Zero Reason" to Expect a Climate Reversal' (Bloomberg Environment \& Energy Report, 15 October 2018) www.bloomberg.com/news/articles/2018-10-15/ trump-says-climate-change-no-hoax-but-will-change-back-again accessed 4 December 2018.

54 Ibid.

55 John McQuaid, 'One Big Legal Obstacle Keeps Trump from Undoing Greenhouse Gas Regulation' (Scientific American, 26 April 2017) www.scientificamerican.com/article/one-big-legal-obstaclekeeps-trump-from-undoing-greenhouse-gas-regulation accessed 4 December 2018.

56 Jeff Brady, “Trump's "Energy Dominance” Gets Slow Start on Federal Land' (National Public Radio, 13 May 2018) www.npr.org/2018/05/13/610684657/trumps-energy-dominance-gets-slow-start-onfederal-land accessed 4 December 2018.

57 Ibid.

58 Mark K Matthews, 'Is a Carbon Tax Part of the Green New Deal?' (E\&E Climatewire, 19 November 2018). 
As if the Trump administration had not made its hostility to climate change clear enough, in the final months of 2018 the EPA's climate change webpage completely disappeared. Those trying to access the EPA's former climate change page now find a message saying, 'We want to help you find what you are looking for', but there is no reference to another webpage. ${ }^{59}$ This followed efforts taken in the first few months of 2017 to take an 'axe to climate change language [in] other government websites'. 60

\subsubsection{Pulling out of the Paris Accords ${ }^{61}$}

One of the first major steps President Trump took to distance himself from the Obama administration's emphasis on reducing greenhouse gas emissions was the June 2017 decision to withdraw the US from the Paris Climate Accords, described as 'the landmark climate accord that sought to bring the world's nations together with the shared goal of keeping climate change to a minimum'. ${ }^{62}$

In a 1 June 2017 announcement, the President said,

I can put no other consideration before the wellbeing of American citizens. The Paris Climate Accord is simply the latest example of Washington entering into an agreement that disadvantages the United States to the exclusive benefit of other countries, leaving American workers ... and taxpayers to absorb the cost in terms of lost jobs, lower wages, shuttered factories, and vastly diminished economic production. ${ }^{63}$

He added, '[A]s of today, the United States will cease all implementation of the nonbinding Paris Accord and the draconian financial and economic burden the agreement imposes on our country. ${ }^{64}$ In Trump's eyes, the agreement aimed to harm the US economically. He said:

The fact that the Paris deal hamstrings the United States, while empowering some of the world's top polluting countries, should dispel any doubt as to the real reason why foreign lobbyists wish to keep our magnificent country tied up and bound down by this agreement: It's to give their country an economic edge over the United States. That's not going to happen while I'm president. ${ }^{65}$

\subsubsection{ENDING THE 'WAR ON COAL'}

During the 2016 presidential campaign, Trump repeatedly accused Obama of having instituted a 'war on coal' and promised that it would be ended if he was elected President. In response, once in office on 28 March 2017, Trump signed an Executive Order

59 See www.epa.gov/sites/pmcquaidroduction/files/signpost/cc.html accessed 4 December 2018.

60 Oliver Milman, "II's a Ghost Page": EPA Site's Climate Change Section May Be Gone for Good' The Guardian (London, 1 November 2018) www.theguardian.com/us-news/2018/nov/01/epa-websiteclimate-change-trump-administration accessed 4 December 2018.

61 The Paris Agreement https://unfccc.int/process-and-meetings/the-paris-agreement/the-paris-agreement accessed 4 December 2018.

62 Matthews (n 40).

63 'Statement by President Trump on the Paris Climate Accord' (1 June 2017) www.whitehouse.gov/ briefings-statements/statement-president-trump-paris-climate-accord accessed 4 December 2018.

64 Ibid.

65 Ibid. 
on Promoting Energy Independence and Economic Growth ${ }^{66}$ and heralded the move, saying, 'Today I'm putting an end to the war on coal. ${ }^{67}$ The Executive Order was described as 'an all-out assault on Barack Obama's climate change legacy' ${ }^{68}$

During the ceremony, which took place in front of a group of coal miners, Trump said, 'C'mon fellas, you know what this says? You're going back to work!' ${ }^{69}$ He noted that during the two-year presidential campaign he had heard about the struggles facing coal miners, and said, 'I made them this promise: we will put our miners back to work. ${ }^{, 70}$

While the Executive Order and some of Trump's subsequent actions have not stopped the decline in US coal usage, 'the industry is thrilled that he's doing his part to try to slow it, especially after eight years of an eco-friendly, climate-concerned Democrat in the White House' ${ }^{71}$ The result of Trump's actions has been described as 'a flurry of coal-friendly actions', 72 which are explored in more detail below.

\subsubsection{RegUlatory ACTIONS}

\subsubsection{In general}

During the first two years of the Trump presidency, a great deal of activity has taken place through executive agency (ie, agencies that report to the President) regulatory actions as contrasted to legislation going through Congress. 'Republicans on the Hill have done a good job of supporting the president and cheerleading his policies, but by and large they haven't been pushing out milestone legislation, per se,' Tom Pyle, President of the American Energy Alliance, has said. ${ }^{73}$ '[S]ome major GOP-led environmental efforts have fallen short [during the 2018-2019] session of Congress, including permitting reform legislation ... and attempts to overhaul the Endangered Species Act,' he said. ${ }^{74}$

In the absence of legislative action on a particular issue, a president can use his executive branch authority to promulgate regulations. As a consequence, 'Over the past several decades, regulation has become one of the most powerful tools a president has for setting policy. ${ }^{75}$ The use of regulations to change law was prominently seen in the Obama administration.

Blocked for most of his presidency by Congress, Mr. Obama ... sought to act however he could. In the process he created the kind of government neither he nor the

66 Presidential Executive Order 13873 on Promoting Energy Independence and Economic Growth (28 March 2017) www.whitehouse.gov/presidential-actions/presidential-executive-order-promotingenergy-independence-economic-growth accessed 4 December 2018.

67 David Smith, 'Trump Moves to Dismantle Obama's Climate Legacy with Executive Order' The Guardian (London, 28 March 2017) www.theguardian.com/us-news/2017/mar/28/trump-clean-power-planexecutive-order-coal-industry accessed 21 November 2018.

68 Ibid

69 Michael Gunwald, 'Trump's Love Affair with Coal' (Politico, 15 October 2017) www.politico.com/ magazine/story/2017/10/15/trumps-love-affair-with-coal-215710 accessed 4 December 2018.

70 Smith (n 67).

71 Gunwald (n 69).

72 Ibid.

73 Robin Bravender, 'What If the GOP Sweeps?' (E\&E News Greenwire, 2 November 2018) www. eenews.net/stories/1060105045 accessed 4 December 2018.

74 Ibid.

75 Stuart Shapiro, 'What New Presidents Can (and Cannot) Do about Regulation' (The Hill, 23 December 2015) https://thehill.com/blogs/pundits-blog/presidential-campaign/264084-what-new-presidents-canand-cannot-do-about accessed 4 December. 
Republicans wanted - one that depended on bureaucratic bulldozing [ie, regulations] rather than legislative transparency. ${ }^{76}$

Thus, it has hardly been a surprise that Trump is using the same executive authority to replace many of Obama's signature climate change-related regulations. In particular, four regulation-related activities have had significant impact on US climate change policy and law.

\subsubsection{New waste prevention (venting and flaring) final rule}

The US Department of the Interior's Bureau of Land Management (BLM) announced on 18 September 2018 a final rule revising the 2016 Methane Waste Prevention Rule. ${ }^{77}$ The new rule ${ }^{78}$ rolls back an Obama-era rule that limited leaked, flared or vented methane from gas and oil wells producing on federal lands. ${ }^{79}$

In announcing the final rule, Interior Department Deputy Secretary David Bernhardt said,

Sadly, the flawed 2016 rule was a radical assertion of legal authority that stood in stark contrast to the longstanding understanding of Interior's own lawyers. The Trump Administration is committed to innovative regulatory improvement and environmental stewardship, while appropriately respecting the clear and distinct authorities of the States, Tribes, as well as the direction we receive from Congress. ${ }^{80}$

Immediately following the announcement of the final rule, the state attorneys general of California and New Mexico sued the Interior Department, contending 'that BLM under President Trump has violated multiple statutes in its unrelenting efforts to wipe the [2016] rule from the books'. ${ }^{81}$ A few days later, 18 environmental groups joined California and New Mexico in the action. ${ }^{82}$

\subsubsection{Affordable Clean Energy (ACE) proposed rule}

The ACE rule, ${ }^{83}$ proposed on 21 August 2018, is aimed at replacing the Obama-era Clean Power Plan (CPP) regulation, ${ }^{84}$ which the Trump administration has described

76 Binyamin Appelbaum and Michael D Shear, 'Once Skeptical of Executive Power, Obama Has Come to Embrace It' New York Times (13 August 2016) www.nytimes.com/2016/08/14/us/politics/obama-eralegacy-regulation.html accessed 4 December.

77 See www.doi.gov/pressreleases/interior-department-finalizes-new-waste-prevention-rule accessed 4 December 2018.

78 See www.gpo.gov/fdsys/pkg/FR-2018-09-28/pdf/2018-20689.pdf accessed 4 December 2018.

79 Ari Natter, 'Trump Relaxes Obama Curbs on Flaring Gas from Wells on U.S. Land (Corrected)' (Bloomberg Environment \& Energy Report, 18 September 2018) www.bloomberg.com/news/articles/2018-0918/trump-relaxes-obama-curbs-on-flaring-gas-from-wells-on-u-s-land accessed 4 December 2018.

80 'Interior Department Finalizes New Waste Prevention Rule' (18 September 2018) www.doi.gov/ pressreleases/interior-department-finalizes-new-waste-prevention-rule accessed 4 December 2018.

81 Pamela King, 'BLM's Final Methane Rule Reveal Draws Swift Legal Action' (E\&E News Energywire, 19 September 2018) www.eenews.net/stories/1060098313 accessed 4 December 2018.

82 Tripp Baltz, 'Environmentalists Sue Over Methane Waste Rule' (Bloomberg Environment \& Energy Report, 1 October 2018).

83 Notice of proposed rulemaking www.gpo.gov/fdsys/pkg/FR-2018-08-31/pdf/2018-18755.pdf accessed 4 December 2018.

84 Final Rule, 'Carbon Pollution Emissions Guidelines for Existing Stationary Sources: Electric Utility Generating Units' Federal Register www.gpo.gov/fdsys/pkg/FR-2015-10-23/pdf/2015-22842.pdf 
as 'overly prescriptive and burdensome' ${ }^{85}$ and Trump has characterised as 'a crushing attack on American industry'. 86

The CPP 'sought to reduce carbon dioxide emissions from power plants by $32 \%$ from their levels in 2005 by 2030 ' ${ }^{87}$ By comparison, the ACE rule

would replace the Obama-era Clean Power Plan's sweeping changes in the US electricity mix with more modest emissions curbs at individual plants. It would set pollution guidelines based on assumptions about what improvement could be eked out through efficiency upgrades at the facilities, then give the states the latitude to design their own plan for paring carbon dioxide emissions at the sites. ${ }^{88}$

According to Andrew Wheeler, Acting EPA Administrator, the proposal would 'restore the rule of law and empower states to reduce greenhouse gas emissions and provide modern, reliable, and affordable energy for all Americans'. ${ }^{89}$ According to Wheeler, the 'proposal provides the states and regulated community the certainty they need to continue environmental progress while fulfilling President Trump's goal of energy dominance'. 90 At the time it was announced, it was reported that 'the move represents the latest bid by Trump to fulfill campaign promises to revive the coal industry and restore mining jobs'. 91

According to one publication, the ACE rule 'is much less ambitious because it would let states decide their emissions-reductions targets (including having none at all). Its name is Orwellian', it was suggested, because 'EPA's own analysis shows that retail electricity price would be reduced by a mere $0.1 \%-0.2 \%$ by 2035 - but that the use of coal, a pollution-belching fuel, would shoot up by as much as $9.5 \%$. ${ }^{92}$

The EPA initially proposed in October 2017 repealing the CPP as a result of the Trump EPA's change in interpreting the Clean Air Act's section 111(d) involving 'best system of emissions reduction' (BSER), on which the Obama EPA had relied when promulgating the CPP.

'The CPP determined that BSER included the replacement of higher-emitting generating with lower-emitting generation supplied via the grid ("generation shifting"). The repeal proposes that the "best" interpretation of Clean Air Act section 111

accessed 4 December 2018. See also ‘Clean Power Plan' website from EPA web archive https://archive. epa.gov/epa/cleanpowerplan.html accessed 4 December 2018.

85 US EPA, 'EPA Proposes Affordable Clean Energy (ACE) Rule' (21 August 2018) www.epa.gov/ newsreleases/epa-proposes-affordable-clean-energy-ace-rule accessed 4 December 2018.

86 David Smith, 'Trump Moves to Dismantle Obama's Climate Legacy with Executive Order' The Guardian (London, 28 March 2017) www.theguardian.com/us-news/2017/mar/28/trump-clean-power-planexecutive-order-coal-industry accessed 4 December 2018.

87 'Smokestack Lightening: The Trump Administration's Latest Plan to Prop Up Coal' The Economist (25 August 2018) 2 www.economist.com/united-states/2018/08/23/the-trump-administrations-latest-planto-prop-up-coal accessed 4 December 2018.

88 Jennifer A Dlouhy, 'Trump Eases Coal-Pollution Curbs in Unwinding More Obama Rules (2)' (Bloomberg Environment \& Energy Report, 21 August 2018).

89 US EPA, 'EPA Proposes Affordable Clean Energy (ACE) Rule' (21 August 2018) www.epa.gov/ newsreleases/epa-proposes-affordable-clean-energy-ace-rule accessed 4 December 2018.

90 Ibid.

91 Dlouhy (n 88).

92 'Smokestack Lightening: The Trump Administration's Latest Plan to Prop Up Coal' The Economist (25 August 2018) 2 www.economist.com/united-states/2018/08/23/the-trump-administrations-latest-planto-prop-up-coal accessed 4 December 2018. 
(a)(1)'s "best system of emission reduction" is limited exclusively to measures that can be applied "inside the fence line",' according to an analysis by the Harvard University School of Law.

The repeal proposal argues - somewhat unclearly and at times inconsistently - that the CPP's interpretation of BSER is impermissible under the plain meaning of the statute. The proposal attempts to demonstrate that the CPP's interpretation is impermissible mostly by way of arguments that affirmatively support the "inside the fence line"-only interpretation of BSER, at times suggesting that this interpretation is simply preferable. ${ }^{93}$

Interestingly enough, the Trump administration was careful to scrub most references to climate change from a very early draft of the ACE rule.

Warnings about potentially severe consequences of climate change were deleted from a Trump administration plan to weaken curbs on power plant emissions during a White House review. Drafts had devoted more than 500 words to highlighting the impacts - more heat waves, intense hurricanes, heavy rainfalls, floods, and water pollution - as part of the proposal to replace Obama-era restrictions on greenhouse gas emissions ... The administration also scrapped a reference to numerous 'major scientific assessments' that 'strengthen the case that GHGs endanger public health and welfare both for current and future generations'. ${ }^{4}$

Amit Narang of the advocacy group Public Citizen said, 'It's clear that EPA decided that it needed to hide any discussion of the harmful impacts of climate change in the regulatory analysis in order to justify, and avoid undermining, the Clean Power Plan rollback.' ${ }^{95}$

The EPA is aiming for March 2019 to finish its repeal of the CPP. ${ }^{96}$ The agency also plans to finalise the ACE rule by about the same date. ${ }^{97}$

Even when the ACE rule is finalised, however, it is likely to encounter serious legal challenges. 'State attorneys general have presented an extraordinarily comprehensive legal argument in opposition to the so-called "Affordable Clean Energy" rule,' according to State Energy and Environmental Impact Center Executive Director David Hayes. ${ }^{98}$

4.1.4.4. Safer Affordable Fuel-Efficient (SAFE) vehicles rules for model years 20212026 proposed rule

In early August 2018 the Trump administration released details about the proposed SAFE rule. ${ }^{99}$

93 Harvard Environmental Law, 'Legal Analysis of the Proposals to Repeal and Replace the Clean Power Plan’ (11 October 2018) https://eelp.law.harvard.edu/2018/10/legal-analysis-of-the-proposals-torepeal-and-replace-the-clean-power-plan accessed 4 December 2018.

94 Jennifer A Dlouhy, 'Dire Climate Change Warnings Cut from Trump Power-Plant Proposal' (Bloomberg Environment \& Energy Report, 4 September 2018) www.bloomberg.com/news/articles/2018-0904/dire-climate-change-warnings-cut-from-trump-power-plant-proposal accessed 4 December 2018.

95 Ibid.

96 www.reginfo.gov/public/do/eAgendaViewRule?pubId=201810\&RIN=2060-AT55.

97 www.reginfo.gov/public/do/eAgendaViewRule?pubId=201810\&RIN=2060-AT67.

98 Pamela King, "AGs on Trump Carbon Rule: "This Will End Up in the Courts"' (E\&E News Energywire, 2 November 2018) www.eenews.net/energywire/2018/11/02/stories/1060104997 accessed 4 December 2018.

99 Notice of proposed rulemaking www.gpo.gov/fdsys/pkg/FR-2018-08-24/pdf/2018-16820.pdf accessed 4 December 2018. 
SAFE, described by a New York Times editorial as 'another big swipe at Mr. Obama's climate agenda', ${ }^{100}$ will roll back part of the Obama administration's automobile fuel efficiency standards. The Obama-era regulation, described as 'one of [his] signature policies to combat global warning', would have substantially reduced America's emissions of greenhouse gases. ${ }^{101}$ By contrast, the Trump proposal envisions freezing 'federal fuel economy requirements at a fleet average of 37 miles per gallon starting in 2020. Under existing Obama-era rules, the average would have risen to roughly 47 miles per gallon by 2025. ${ }^{102}$ Additionally, SAFE will reduce standards for carbon dioxide emissions from tailpipes. ${ }^{103}$ Finally, the rule will revoke California's authority through a federal waiver to establish stricter tailpipe emissions standards than the federal government, ${ }^{104}$ a right that has been 'a powerful tool the state has used to try to curb greenhouse gas emissions.' ${ }^{105}$

In announcing the proposed rule, EPA Acting Administrator Andrew Wheeler said, 'We are delivering on President Trump's promise to the American public that his administration would address and fix the current fuel economy and greenhouse gas emissions standards ... More realistic standards can save lives while continuing to improve the environment. ${ }^{106}$ Trump officials have said that the proposed rule will reduce the cost of cars 'and therefore allow people to replace older and less-safe vehicles more rapidly'. ${ }^{107}$ The EPA and the US Department of Transportation, which jointly announced the proposal, said:

The current standards have been a factor in the rising cost of new automobiles to an average of $\$ 35,000$ or more - out of reach for many American families. Indeed, compared to the preferred alternative in the proposal, keeping in place the standards finalized in 2012 would add $\$ 2,340$ to the cost of owning a new car, and impose more than $\$ 500$ billion in societal costs on the U.S. economy over the next 50 years. ${ }^{108}$

In the wake of the announcement of the proposed rule, one publication observed, 'Of the many climate rollbacks the Trump administration has undertaken, its

100 Editorial, 'In California, Facts and Science Still Matter' New York Times (3 September 2018) www. nytimes.com/2018/09/03/opinion/california-climate-change-renewable-energy.html accessed 4 December 2018.

101 Coral Davenport, 'Trump Unveils His Plan to Weaken Car Pollution Rules' New York Times (2 August 2018) www.nytimes.com/2018/08/02/climate/trump-auto-emissions-california.html accessed 4 December 2018 .

102 John Lippert and Ryan Beene, 'California to Fight "Unlawful" Trump Fuel Economy Rollback' (Bloomberg Environment \& Energy Report, 24 October 2018).

103 John Lippert and Joyce E Cutler, 'California Doesn't See Court Fight on Trump Emissions Challenge' (Bloomberg Environment and Energy Report, 11 September 2018).

104 Ibid.

105 Merrit Kennedy and Camila Domonoske, 'White House Proposal Rolls Back Fuel Economy Standards, No Exception for California' (National Public Radio, 2 August 2018) www.npr.org/2018/08/02/ 631986713/white-house-proposal-rolls-back-fuel-economy-standards-no-exception-for-californ accessed 4 December 2018.

106 EPA, 'U.S. EPA and DOT Propose Fuel Economy Standards for MY 2021-2026 Vehicles' (2 August 2018) www.epa.gov/newsreleases/us-epa-and-dot-propose-fuel-economy-standards-my-2021-2026vehicles accessed 4 December 2018.

107 Lippert and Beene (n 102).

108 EPA, 'U.S. EPA and DOT Propose Fuel Economy Standards for MY 2021-2026 Vehicles' (2 August 2018) www.epa.gov/newsreleases/us-epa-and-dot-propose-fuel-economy-standards-my-2021-2026vehicles accessed 4 December 2018. 
proposal to freeze vehicle fuel efficiency standards stands to increase emissions the most. ${ }^{109}$ Natural Resources Defense Council Climate and Energy Strategic Director, David Doniger, said, 'I think it's fair to say that if they're successful in rolling back the clean car and fuel economy standards, it would be the biggest step backwards on greenhouse gas emissions.' ${ }^{110}$ Similarly, Rep Nancy Pelosi (D-Cal) described the proposal as a 'dangerous assault on clean air and public health in California and across the nation'.11

The Trump administration hopes to finalise the rule in $2019,{ }^{112}$ a timeline that has been described as 'extremely ambitious'. ${ }^{113}$

4.1.4.5. Oil and natural gas sector: emission standards for new, reconstructed and modified sources reconsideration rule (methane replacement rule) proposed rule

The proposed rule, ${ }^{114}$ announced on 11 September 2018, has been referred to as another 'major step' in the Trump administration's efforts to roll back Obama-era efforts to address climate change. ${ }^{115}$ The purpose of the rule is to 'relax Obama-era mandates meant to block rogue methane leaks from oil and gas wells'. ${ }^{116}$ In announcing the proposal, EPA Acting Administrator Andrew Wheeler said, 'These common-sense reforms will alleviate unnecessary and duplicative red tape and give the energy sector the regulatory certainty it needs to continue providing affordable and reliable energy to the American people.' 117

Among other things, the proposed rule 'would lessen the frequency of required inspections to hunt for methane leaks, remove a requirement that professional engineers certify some equipment designs, and make it easier for energy companies to deploy emerging technologies to monitor emissions'. 118

109 Zack Coleman, 'Trump Makes His Biggest Move on Climate with Car Rules' (E\&E News Climatewire, 3 August 2018) www.eenews.net/climatewire/stories/1060092681/most_read accessed 22 November 2018.

110 Ibid.

111 Maxine Joselow, 'Trump Proposes Rollback of Obama's Clean Car Rules' (E\&E News, 2 August 2018) www.eenews.net/stories/1060091945 accessed 4 December 2018.

112 See https://reginfo.gov/public/do/eAgendaViewRule?pubId=201810\&RIN=2060-AU09 accessed 4 December 2018.

113 Niina Heikkinen, 'EPA Has "Extremely Ambitious" Timeline for Climate Rules' (E\&E News Greenwire, 23 October 2018) www.eenews.net/greenwire/stories/1060104093 accessed 4 December 2018.

114 Notice of proposed rulemaking www.gpo.gov/fdsys/pkg/FR-2018-10-15/pdf/2018-20961.pdf accessed 4 December 2018.

115 Coral Davenport, 'Trump Administration Wants to Make It Easier to Release Methane into Air' New York Times (10 September 2018) www.nytimes.com/2018/09/10/climate/methane-emissionsepa.html accessed 4 December 2018.

116 Jennifer A Dlouhy, 'Obama Methane Rules for Oil Wells Reined in Under EPA Proposal (1)' (Bloomberg Environment \& Energy Report, 11 September 2018) https://news.bloombergenvironment.com/ environment-and-energy/obama-methane-rules-for-oil-wells-reined-in-under-epa-proposal-1 accessed 4 December 2018.

117 'EPA Proposes Oil and Gas Targeted Improvements Package to Advance President Trump's Energy Dominance Agenda' (11 September 2018) www.epa.gov/newsreleases/epa-proposes-oiland-gas-targeted-improvements-package-advance-president-trumps-energy accessed 4 December 2018 .

118 Dlouhy (n 116). 
Adoption of the new rule, which has been praised by the trade group the American Petroleum Institute, ${ }^{119}$ will save industry money. ${ }^{120}$ However, the EPA's analysis said 'the proposed [rule] could pump hundreds of thousands more tons of the climate-warming gas into the atmosphere and add millions of dollars in agricultural, health-care and other costs to the U.S. economy because of climate change.' 121

This rule was the EPA's second endeavour to change the Obama-era requirements. A US federal court in July 2017 rebuked the EPA's initial efforts that were based on suspending the mandates unilaterally. ${ }^{122}$

\subsection{Judicial-related activities}

\subsubsection{Selection of Federal Judges}

One of a president's most important roles is to nominate judges for the US federal courts as well as justices for the US Supreme Court. While these nominations are subject to US Senate confirmation, the reality is that most nominees are confirmed. Trump has actively nominated judges who, when confirmed, will serve for life as members of the federal judiciary.

\subsubsection{Confirmation of Justice Kavanaugh}

Brett M Kavanaugh was sworn in on 6 October 2018 as a member of the US Supreme Court. ${ }^{123}$ His nomination by Trump likely represents one of the most enduring decisions that the President has made in his first two years in office.

Kavanaugh's confirmation by the US Senate is all the more consequential since he took the seat of retired Associate Justice Anthony Kennedy, who 'was often a swing vote on the ideologically divided court, and... played a key role in several major environmental cases'. ${ }^{124}$ For example, in 2007, Justice Kennedy joined the majority opinion in Massachusetts $v$ EPA, which established the authority of the EPA to regulate greenhouse gases. ${ }^{125}$ Moreover, many environmental advocates who already consider

119 Niina Heikkinen, 'EPA Plan: Increased Emissions, “Adverse” Health Effects' (E\&E Greenwire, 11 September 2018) www.eenews.net/greenwire/stories/1060096529?t=https\%3A\%2F\%2Fwww.eenews.net \%2Fstories\%2F1060096529 accessed 4 December 2018.

120 Dino Grandoni, 'The Energy 202: Even the EPA Acknowledges Its New Methane Rule May Be Costly' Washington Post (12 September 2018) www.washingtonpost.com/news/powerpost/ paloma/the-energy-202/2018/09/12/the-energy-202-even-the-epa-acknowledges-its-new-methanerule-may-be-costly/5b9831241b326b47ec959565/?utm_term=.2a74b56fac98 accessed 4 December 2018.

121 Ibid.

122 Dlouhy (n 116).

123 See www.supremecourt.gov/publicinfo/press/pressreleases/pr_10-06-18 accessed 4 December 2018.

124 Mark K Matthews, 'Kavanaugh Fight Has Big Consequences for Climate Law' (E\&E News Climatewire, 27 September 2018) www.eenews.net/climatewire/stories/1060099893 accessed 4 December 2018.

125 Massachusetts v Environmental Protection Agency, 549 US 497 (2007) www.supremecourt.gov/ opinions/boundvolumes/549bv.pdf accessed 4 December 2018. 
the Supreme Court 'an unfriendly venue' have said that Kavanaugh's appointment to the Court will 'take it further to the right"126 and push the Court 'to be far more hostile to federal regulations'. 127

Having been referred to as 'an influential conservative critic of sweeping environmental regulations', Kavanaugh, as a member of the US Court of Appeals for the District of Columbia Circuit,

voted in a number of high-profile cases to limit Environmental Protection Agency rules involving issues like climate change and air pollution ... His legal philosophy was clear: In the absence of explicit instructions from Congress, any far-reaching efforts by the E.P.A. to tackle environmental problems should be met with deep skepticism by the courts. That philosophy often put him sharply at odds with the Obama Administration, which sought to harness old environmental laws to deal with newer challenges like global warming. ${ }^{128}$

A particularly key issue when it comes to the courts and federal agencies is the extent to which a court will defer to an agency's interpretation of an ambiguous statute. The extent of deference a court extends to an agency often arises in the context of environmental regulations. ${ }^{129}$ This issue arose in Kavanaugh's September and October 2018 confirmation hearings before the US Senate Judiciary Committee in the context of his views about a 1984 Supreme Court decision, Chevron USA Inc v Natural Resources Defense Council, ${ }^{130}$ which has been characterised as a 'landmark'131 decision. 'Chevron deference', in reference to one of the outcomes of that decision, is a major principle in administrative law, providing that

when a legislative delegation to an administrative agency or on a particular issue or question is not explicit but rather implicit, a court may not substitute its own interpretation of the statute for a reasonable interpretation made by the administrative agency. Rather... when the statute is silent or ambiguous with respect to the specific issue, the question for the court is whether the agency's action was based on permissible construction of the statute. ${ }^{132}$

In the hearings, Kavanaugh expressed frustration with the Chevron doctrine and contended that in some instances agencies imagine that an old law provides the agency authority and then subsequently claim an entitlement to judicial deference. ${ }^{133}$ In responding to questions about the principle, Kavanaugh said that too often the

126 Ellen M Gilmer, 'Kavanaugh Dishes on Chevron, Environmental Law’ (E\&E Daily, 7 September 2018) www.eenews.net/eedaily/2018/09/07/stories/1060096189 accessed 4 December 2018.

127 Brad Plumer, 'How Brett Kavanaugh Could Reshape Environmental Law from the Supreme Court' New York Times (10 July 2018) www.nytimes.com/2018/07/10/climate/kavanaugh-environmentsupreme-court.html accessed 4 December 2018.

128 Ibid.

129 Ellen M Gilmer, 'Kavanaugh Tackles Doctrine That Loomed over Climate Plan' (E\&E News Climatewire, 6 September 2018) www.eenews.net/stories/1060095983 accessed 4 December 2018.

130 Chevron USA Inc v Natural Resources Defense Council, 467 US 837 (1984), https://cdn.loc.gov/ service/11/usrep/usrep467/usrep467837/usrep467837.pdf accessed 4 December 2018.

131 Ellen M Gilmer, 'Kavanaugh Defends His Environmental Record' (E\&E News Greenwire, 5 September 2018) www.eenews.net/stories/1060095913 accessed 4 December 2018.

132 Cornell University Law School Legal Information Institute, 'Chevron Deference' www.law.cornell.edu/ wex/chevron deference accessed 4 December 2018.

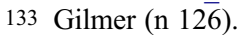


executive branch, when unable to persuade Congress to change or enact a law, attempts to derive new authority to act by regulation. 'It's a natural phenomenon because the executive wants to implement what it thinks is a good policy,' he said. ${ }^{134}$ 'We don't write those laws,' he said, adding, 'The executive branch also shouldn't be rewriting those laws. ${ }^{, 135}$ He went on to say that in general he is not sceptical of all regulation.

I've heard it said that I'm a skeptic of regulation. I'm not a skeptic of regulation at all.

I'm a skeptic of unauthorized regulation, illegal regulation that is outside the bounds of what the laws passed by the Congress have said. ${ }^{136}$

Jody Freeman, the Founding Director of the Harvard Law School Environmental and Energy Program, has observed, 'Kavanaugh is temperamentally and philosophically skeptical about the exercise of government power, especially when agencies act expansively, and find new powers in longstanding laws. ${ }^{, 137}$

Kavanaugh said in the hearings that in some cases involving regulations the 'major questions' doctrine should be considered as part of the court's consideration. ${ }^{138}$ Specifically, he referenced the 2014 decision in Utility Air Regulatory Group v EPA, ${ }^{139}$ which held that the EPA was prohibited from exercising 'transformative power without a "clear statement" from Congress on an issue'. ${ }^{140}$ Kavanaugh said, 'What the opinion says is it's okay for Congress to delegate various matters to the executive agencies to do rules, but on major questions of major economic or social significance, we expect Congress to speak clearly before such a delegation. ${ }^{141}$ One Republican energy lobbyist has said, 'There's very little doubt in my mind that Chevron deference is going to get breached here shortly,' adding that such an outcome will open the door to 'any lawyer who's ever been [unhappy] with any agency interpretation' to argue their case. ${ }^{142}$ On the other hand, environmental advocates have expressed concern that Kavanaugh applies an 'overly narrow view of agency authority'. ${ }^{143}$

With respect to climate change-related matters in particular, Kavanaugh has been described as 'a well-known skeptic of the EPA's authority to regulate greenhouse gases'. ${ }^{144}$ In cases that came before the US Court of Appeals for the District of Columbia Circuit while he was a member, he took the position that Congress should be the governmental branch that dictates policy related to climate. ${ }^{145}$ For example, in the

\footnotetext{
134 Fatima Hussein, 'Kavanaugh Touts Environment Rulings, Says He's Not Anti-Regulation' (Bloomberg Environment \& Energy Report, 5 September 2018) https://news.bloombergenvironment.com/ environment-and-energy/kavanaugh-touts-environment-rulings-says-hes-not-anti-regulation accessed 4 December 2018.

135 Gilmer (n 131).

136 Ibid.

137 'Daily on Energy' Washington Examiner (8 October 2018).

138 Gilmer (n 129).

139 Utility Air Regulatory Group v EPA, 573 US 573/12-1146 accessed 4 December 2018.

140 Gilmer (n 129).

141 Ibid.

142 Ellen M Gilmer and Robin Bravender, 'Conservatives Stake Claim on New Supreme Court' (E\&E Greenwire, 8 October 2018) www.eenews.net/stories/1060100745 accessed 4 December 2018.

143 Gilmer (n 131).

144 Abby Smith, 'Kavanaugh Would Add Skeptic of EPA Climate Authority to High Court' (Bloomberg Environment \& Energy Report, 10 July 2018).

145 Ibid.
} 
2017 decision Mexichem Fluor Inc v EPA, ${ }^{146}$ where large portions of an Obama-era EPA regulation limiting the use of hydrofluorocarbons were struck down, then Judge Kavanaugh wrote, 'Climate change is not a blank check for the President,' adding, 'However much we might sympathize or agree with EPA's policy objectives, EPA may only act within the boundaries of its statutory authority. ${ }^{147}$ Similarly, in oral arguments before the DC Circuit in a 2016 case involving the legality of the Obama-era Clean Power Plan rule, Kavanaugh gave indications that the rule was 'fundamentally transforming an industry' and 'Congress should be making [these types of] big policy decisions. ${ }^{148}$ John Cruden, former US Department of Justice Head of the Environment and Natural Resources Division under Obama, said that the questions Kavanaugh asked at the oral argument suggested 'his skepticism over the Obama administration's broad reading of its authority under the Clean Air Act'. ${ }^{149}$ Ultimately, the DC Circuit put the case on hold pending the Trump administration's 'crafting a weaker replacement rule'. 150

Looking ahead, there are several important climate change-related cases that will or may make their way to the Supreme Court, which now includes Justice Kavanaugh:

- On 31 October 2018, the Court heard the case of Jam v the International Finance Corporation (IFC). The case was an appeal of a lower court ruling that held that villagers in India cannot hold the Washington, DC-based IFC liable for environmental damage they assert was caused by its financing of a power plant. 'Without the IFC's funding', the plaintiffs asserted, the coal-fired plant would not have gone ahead. ${ }^{151}$ According to the plaintiffs, 'the local environment has been devastated ... with marine life killed by water discharged from the plant's cooling system and coal dust contaminating the air'. ${ }^{152}$ The legal issue presented to the Court was are there 'limits to immunity for entities like the IFC under the 1945 International Organizations Immunity Act, as there are for foreign countries under a 1976 law called the Foreign Sovereign Immunities Act'? ${ }^{153}$

- Once the ACE rule is finalised, it will likely draw immediate suits from environmental groups and some states, which will argue that it does not do enough to protect public health or reduce carbon emissions. ${ }^{154}$ Put even more bluntly, a

146 Mexichem Fluor Inc v EPA, No 15-1328, decided 8 August 2017 www.cadc.uscourts.gov/internet/ opinions.nsf/3EDC3D4817D618CF8525817600508EF4/\$file/15-1328-1687707.pdf $\quad$ accessed 4 December 2018.

147 Ibid.

148 Gilmer (n 129).

149 Fatima Hussein, 'Kavanaugh's “Standing Position” Threatens Pollution Suits: Attorneys' (Bloomberg Environment \& Energy Report, 5 September 2018) https://news.bloombergenvironment.com/ environment-and-energy/kavanaughs-standing-position-threatens-pollution-suits-attorneys accessed 4 December 2018.

150 Gilmer (n 129).

151 Mark K Matthews, 'Kavanaugh Fight Has Big Consequences for Climate Law' (E\&E News Climatewire, 27 September 2018) www.eenews.net/climatewire/stories/1060099893 accessed 4 December 2018.

152 Lawrence Hurley, 'U.S. Supreme Court Takes up Dispute over Power Plant in India' (Reuters, 21 May 2018) www.reuters.com/article/us-usa-court-india/u-s-supreme-court-takes-up-dispute-over-powerplant-in-india-idUSKCN1IM1EB accessed 4 December 2018.

153 Ibid.

154 Matthews (n 151). 
challenge to the ACE, which will replace the Obama-era Clean Power Plan rule, is 'inevitable', according to former US Department of Justice Head of Natural Resources and Environment division John Cruden. ${ }^{155}$ The matter could possibly reach the Court, where it has been suggested that Kavanaugh 'would likely favor the Trump administration EPA's narrow approach to regulating carbon from coal power plants'. 156

- In Juliana $v$ United States, 21 children and young adult plaintiffs are asserting the "far-reaching argument"157 that the federal government has known for decades that carbon dioxide pollution was causing catastrophic climate change and that massive emissions reductions are needed to protect their constitutional rights to life, liberty and property. ${ }^{158}$ The plaintiffs are seeking a court declaration that their rights have been violated by the federal government as well as an order mandating development of a plan to end the use of fossil fuels. ${ }^{159}$ Currently being considered by the US Federal Court in the District of Oregon, it appears the case is 'bound, tractor-beam-like, for the Supreme Court' 160

\subsubsection{CONFIRMATION OF OTHER FEDERAL JUDGES}

In addition to the nomination of justices to the US Supreme Court, Trump is also busy reshaping the membership of the federal judiciary as a whole. It has been observed that even if the Democrats recapture the White House and the Senate in 2020, '[T]hey're losing the federal courts for the long term, as President Donald Trump is rapidly ensconcing a conservative judiciary that will have the power to knock down liberal policies for decades to come. ${ }^{161}$ The increasing number of Trump-appointed judges in the lower federal courts is 'likely to impose higher hurdles for citizens seeking to challenge government actions under foundational environmental laws like the Clean Water Act, swinging the legal odds toward big business even under the most progressive future Democratic presidents'. ${ }^{162}$

The importance of the federal judiciary's potential role in climate change in particular has been underscored by the observation, '[T]he courtroom is the last stand for enacting policies to limit greenhouse gases, as the White House scarcely acknowledges climate change and Congress remains deadlocked. ${ }^{163}$

155 Hussein (n 149).

156 'Daily on Energy' (n 137).

157 Matthews (n 151).

158 Juliana $v$ United States, First Amended Complaint for Declaratory and Injunctive Relief, Case No: 6:15-cv-01517-TC (10 September 2015) 94 http://blogs2.law.columbia.edu/climate-change-litigation/ wp-content/uploads/sites/16/case-documents/2015/20150910_docket-615-cv-1517_complaint-1.pdf accessed 4 December 2018.

159 Matthews (n 151).

160 Ibid.

161 Adam Cancryn, 'Even If Democrats Win, Trump Has Them Beat on the Courts' (Politico, 5 November 2018) www.politico.com/story/2018/11/05/trump-courts-elections-judges-960754 accessed 4 December 2018.

162 Ibid.

163 Umair Irfan, 'A Major Climate Change Lawsuit is on Hold. Again.' (Vox, 4 December 2018) www.vox. com/2018/11/2/18029146/climate-change-lawsuit-children-scotus-supreme-court-juliana accessed 4 November 2018. 


\section{3. $\quad$ Other matters involving the Trump administration}

\subsubsection{DownGrading THE EPA's ROLE}

During the 2016 presidential campaign, Trump promised to dismantle the EPA. For example, in a March 2016 primary campaign debate he said he would eliminate what he referred to as 'the Department of Environment Protection' meaning, presumably, the EPA. ${ }^{164}$ 'We're going to have little tidbits left, but we are going to get most of it out,' he said. ${ }^{165}$ Since taking office, Trump is 'making headway on that promise'. ${ }^{166}$ As of mid-2018, the EPA has suffered a net loss of 1,200 employees, a level reminiscent of the Ronald Reagan administration. ${ }^{167}$ According to a Washington Post analysis, 'at least 260 scientists, 185 "environmental protection specialists," and 106 engineers are gone'. 168

Besides the hollowing out of the EPA workforce, the EPA is also departing 'from historical norms' where an agency either retained the status quo or enacted stricter regulations, Georgetown University Law School Professor William Buzbee has observed. ${ }^{169}$ The topic of coal regulation provides one example. Professor Buzbee said,

When you look collectively at [the Trump administration's] array of regulatory proposals and in some instances regulatory actions, I think without exception they are providing regulatory relief or greater regulatory flexibility to coal-related businesses or regulators of coal-related businesses. It's a fundamental moving of the goal posts back; it's asking less and allowing more time to get there. ${ }^{170}$

The Trump administration has also sought to significantly reduce funding for climaterelated work. In this regard, hundreds of millions of dollars were targeted for elimination in Trump's fiscal year 2019 budget. ${ }^{171}$ Ultimately, however, congressional appropriators rejected Trump's proposals and the EPA and Department of the Interior programmes related to climate science received funding boosts. ${ }^{172}$ Nevertheless, some say Trump's proposals have hurt morale in the EPA. For instance, former EPA Climate Change Division Director Dina Kruger has said,

164 Kyle Feldscher, 'Trump Says He'd Eliminate "Department of Environment Protection" Washington Examiner (3 March 2016) www.washingtonexaminer.com/trump-says-hed-eliminate-department-ofenvironment-protection accessed 4 December 2018.

165 Ibid.

166 Brady Dennis, Juliet Eilperin and Andrew Ba Tran, 'With a Shrinking EPA, Trump Delivers on His Promise to Cut Government' Washington Post (8 September 2018) www.washingtonpost.com/ national/health-science/with-a-shrinking-epa-trump-delivers-on-his-promise-to-cut-government/2018/ 09/08/6b058f9e-b143-11e8-a20b-5f4f84429666_story.html?noredirect=on\&utm_term $=$. 23c26dc096b5 accessed 7 October 2018.

167 Brady Dennis, Juliet Eilperin and Andrew Ba Tran, 'With a Shrinking EPA, Trump Delivers on His Promise to Cut Government' Washington Post (8 September 2018) www.washingtonpost.com/ national/health-science/with-a-shrinking-epa-trump-delivers-on-his-promise-to-cut-government/2018/ 09/08/6b058f9e-b143-11e8-a20b-5f4f84429666_story.html?noredirect=on\&utm_term=. 23c26dc096b5 accessed 4 December 2018.

168 Ibid.

169 Niina Heikkinen, '8 Ways That EPA's Helping the Coal Industry' (E\&E News Greenwire, 17 September 2018) www.eenews.net/greenwire/2018/09/17/stories/1060097285 accessed 4 December 2018.

170 Ibid.

171 Maxine Joselow, “It's Not a Happy Place”" (E\&E Climatewire, 21 November 2018) www.eenews.net/ stories/1060107165 accessed 4 December 2018.

172 Ibid. 
In my view, the majority of career staff at EPA are going to do what they can do ... [B]ut they are not going to try that hard, and they are certainly not going to be burning the midnight oil doing the kinds of rules that we were doing during the Obama administration. ${ }^{173}$

Finally, there has been concern by the EPA's scientists about 'the Trump administration's systematic and unprecedented effort to undermine the way in which science is used by the agency. Scientists there say they and their work have been largely ignored by senior EPA leadership. ${ }^{174}$ According to Kyla Bennett of the Public Employees for Environmental Responsibility, an organisation that directly works with public employee whistleblowers, 'There's a lot of fear, a lot of angst and anxiety, and employees don't know what to do. This is unlike anything we've ever seen. ${ }^{175}$ In a related matter, in September 2018 it was announced that the EPA would eliminate the Office of Science Advisor. ${ }^{176}$ According to the EPA website, 'The Science Advisor works across the agency to ensure that the highest quality science is better integrated into the agency's policies and decisions. ${ }^{177}$ After the announcement, National Public Radio reported, 'The EPA [described] the move as an effort to streamline the agency, but critics [regarded] it as another move by the Trump administration to diminish the role of science in decision making. ${ }^{178}$ The impact of this action was described as diminishing 'the role of scientific research in policymaking while the administration pursues an agenda of rolling back regulations'. ${ }^{179}$

\subsubsection{ENERGY DOMINANCE AND PRODUCING MORE OIL AND GAS ON FEDERAL LANDS}

The theme of 'energy dominance' has become a key natural resources and economic priority of the Trump administration. In a speech to the US Department of Energy on 29 June 2017, Trump said his administration would:

seek not only American energy independence that we've been looking for so long, but American energy dominance. And we're going to be an exporter - exporter. We will be dominant. We will export American energy all over the world, all around the globe. These energy exports will create countless jobs for our people. ${ }^{180}$

In his speech, Trump mentioned several initiatives to promote energy dominance, including repealing Obama-era climate change regulations, ending 'the war

173 Ibid.

174 Jeff Tollefson, 'Science under Siege: Behind the Scenes at Trump's Troubled Environment Agency' Nature (12 July 2018) www.nature.com/articles/d41586-018-05706-9 accessed 4 December 2018.

175 Ibid.

176 Dan Boyce, 'EPA to Dissolve Office of Science Advisor' (NPR Weekend All Things Considered, 29 September 2018) www.npr.org/2018/09/29/653013054/epa-to-dissolve-office-of-science-advisor accessed 24 November 2018.

177 EPA, 'About the Office of the Science Advisor' www.epa.gov/aboutepa/about-office-science-advisor accessed 4 December 2018.

178 See n 176.

179 Coral Davenport, 'E.P.A. to Eliminate Office That Advises Agency Chief on Science' New York Times (27 September 2018) www.nytimes.com/2018/09/27/climate/epa-science-adviser.html accessed 4 December 2018.

180 US Department of Energy, 'Remarks by President Trump at the Unleashing American Energy Event' (29 June 2017) www.whitehouse.gov/briefings-statements/remarks-president-trump-unleashingamerican-energy-event accessed 4 December 2018. 
on coal', withdrawing from the Paris Climate Accord, reducing restrictions on natural gas development and cancelling the moratorium on new coal leasing on federal lands. ${ }^{181}$

The energy dominance plan 'also means using the country's [resources] - particularly liquefied natural gas, or LNG - as a bargaining chip in the international arena to provide energy security to allies'. ${ }^{182}$

In October 2018, the US Department of the Interior released the 'Fiscal Year 2017 Economic Contributions' report. ${ }^{183}$ The Department, which manages 20 per cent of the country's land, ${ }^{184}$ said the data showed 'the Trump administration's promotion of energy development on federal lands is generating billions of dollars in revenue and hundreds of thousands of jobs'. ${ }^{185}$ According to the report, production quantities of crude oil and coal rose from Fiscal Year 2016 to Fiscal Year 2017 while natural gas production was down slightly. ${ }^{186}$ Overall, the economic impact as measured by the report showed an increase of $\$ 400 \mathrm{~m}$ in the first year of the Trump administration. ${ }^{187}$ The economic output increase was 'thanks in part to [the] American Energy Dominance' programme according to the Interior Department. ${ }^{188}$

The Western Energy Alliance, an industry group headquartered in Denver, Colorado, has enthusiastically supported the Trump administration's efforts to reduce barriers that it believed the Obama-era Bureau of Land Management was erecting for firms that wanted to explore for oil and gas on federal lands. ${ }^{189}$ Interior Secretary Ryan Zinke said, 'This report shows that thanks to smart regulatory reforms and increased access, federal lands and waters are once again increasing economic output and creating jobs. ${ }^{190}$

However, the report was attacked by conservationists. The Center for Biological Diversity's Director of Public Lands Program, Randi Spivak, said, 'The true costs of opening these beautiful wild places to destructive drilling and mining are far greater than any short-term revenues. ${ }^{191}$ In addition, environmental advocates have long argued that public lands management should take into consideration pollution and climate change concerns. ${ }^{192}$

181 Ibid.

182 Justin Worland, 'President Trump Says He Wants “Energy Dominance." What Does He Mean?' Time Magazine (30 June 2017) http://time.com/4839884/energy-dominance-energy-independence-donaldtrump accessed 4 December 2018.

183 US Department of the Interior, 'US Department of Interior Economic Report for Fiscal Year 2017' (19 October 2018) https://doi.sciencebase.gov/doidv accessed 4 December 2018.

184 Ibid.

185 Scott Streater, 'Interior Touts Economic Benefits of "Energy Dominance", (E\&E News Greenwire, 14 November 2018) www.eenews.net/greenwire/2018/11/14/stories/1060106217 accessed 4 December 2018.

186 US Department of the Interior (n 183).

187 US Department of the Interior, 'Economic Impact of Public Lands Increases by \$400 Million in First Year Under President Trump' (14 November 2018) www.doi.gov/pressreleases/economic-impactpublic-lands-increases-400-million-first-year-under-president-trump accessed 4 December 2018.

188 Ibid.

189 Brady (n 56).

190 US Department of the Interior (n 187).

191 Streater (n 185).

192 Brady (n 56). 


\subsubsection{BAILOUT/PROPPING UP COAL AND NUCLEAR POWER PLANTS}

The Trump administration has employed several strategies in an effort to aid the coal mining and coal-fired electricity sectors. First, the Trump EPA's coal-related regulatory agenda has benefited both sectors. In this regard, Harvard Environmental Law Program Executive Director, Joseph Goffman, has said,

I think we are seeing an inversion where the [EPA] ... [is] almost using deregulation as a sort of backdoor way of if not subsidizing coal-fired generation, then at least privileging it by shielding it from paying for the cost of reducing pollution and waste and transferring those costs back to the public. ${ }^{193}$

In addition, in September 2017, US Department of Energy Secretary Rick Perry urged the Federal Energy Regulatory Commission (FERC) to issue a final rule requiring the market it regulates to implement reforms that would prop up financially stressed coalfired and nuclear power plants. ${ }^{194}$ The reliability order rule would have guaranteed 'financial return for any power plant that could stockpile 90 days' worth of fuel onsite, which could include many coal and nuclear plants'. ${ }^{195}$ However, in January 2018, FERC turned down the request. ${ }^{196}$

Subsequently, in October 2018, US Interior Department Secretary Ryan Zinke said that the administration was considering using West Coast military bases as possible locations for coal and gas export facilities, thus circumventing statebased opposition to such terminals. 'I respect the state of Washington and Oregon and California. But also it's in our interests for national security and our allies to make sure that they have access to affordable energy commodities,' Zinke said. ${ }^{197}$ Invoking national security in this context 'highlights the limited tools available to the administration in its effort to aid the coal industry' analysts suggested. ${ }^{198}$ David Victor, Co-Director of the University of San Diego Laboratory on International Law and Regulations, said, 'When you want to intervene in the energy markets, national security is the nuclear option. That's what they tried to do with the [FERC] reliability order and it sounds like what they're trying to do here.' 199

193 Heikkinen (n 169).

194 Department of Energy, 'Secretary Perry Urges FERC to Take Swift Action to Address Threats to Grid Resiliency' (29 September 2018) www.energy.gov/articles/secretary-perry-urges-ferc-take-swiftaction-address-threats-grid-resiliency accessed 4 December 2018.

195 Brad Plumer, 'Trump Orders a Lifeline for Struggling Coal and Nuclear Plants' New York Times (1 June 2018) www.nytimes.com/2018/06/01/climate/trump-coal-nuclear-power.html accessed 4 December 2018.

196 Federal Energy Regulatory Commission, 'Order Terminating Rulemaking Proceeding, Initiating New Proceeding, and Establishing Additional Procedures' (8 January 2018) www.ferc. gov/media/news-releases/2018/2018-1/01-08-18.asp\#.W_sU3C2ZNBw accessed 4 December 2018.

197 Benjamin Storrow, 'Trump Turns to National Security to Boost Coal' (E\&E News Climatewire, 16 October 2018) www.eenews.net/climatewire/2018/10/16/stories/1060102629 accessed 4 December 2018.

198 Ibid.

199 Ibid. 


\subsubsection{Shrinking NATIONAL MONUMENTs ${ }^{200}$}

In 1906, President Theodore Roosevelt signed into law the American Antiquities Act. ${ }^{201}$ This act 'was created in recognition of the very slow process of enacting federal legislation'202 to protect 'historic landmarks, historic and prehistoric structures, and other objects of historic or scientific interest' that are on federal property. ${ }^{203}$ Subsequently, the Act became a tool used by many presidents to create national monuments, which are nationally significant lands and waters that are set aside for permanent protection. ${ }^{204}$ Although national monuments are created by the executive branch, they are often later designated as a national park by the legislative branch. For example, the Grand Canyon was established as a national monument by President Roosevelt in 1908 and redesignated as a national park by Congress in $1919 .^{205}$

As one of his first initiatives, Trump on 26 April 2017 issued Executive Order 13792, which directed the Secretary of Interior Ryan Zinke to review every national monument designation since 1996 that is larger than 100,000 acres. ${ }^{206}$ This was a highly contested action since it is unclear whether a president can diminish in size an already existing national monument designated by a prior president. In the eyes of some observers the reductions were 'a highly symbolic salvo in a larger campaign to reverse Obama-era public land policies'. ${ }^{207}$

In issuing the order, Trump characterised national monument designations as a 'massive federal land grab', ${ }^{208}$ and said, 'The previous administration used a 100year-old law ... to put millions of acres of land and water under strict federal control, eliminating the ability of the people who actually live in those states to decide how best to use that land. ${ }^{209}$ In explaining his action, he said,

I've spoken with many state and local leaders ... who care very much about conserving land and are gravely concerned about this massive federal land grab ... it has gotten

200 The authors would recognise Rachael Kamlet, a Juris Doctor graduate of Nova Southeastern University and a May 2019 candidate for an LLM in Environment and Natural Resources Law from the University of Denver Sturm College of Law for her help in writing this section.

201 See www.nps.gov/history/local-law/anti1906.htm accessed 4 December 2018.

202 Robert Rosenbaum and others (Arnold \& Porter and Kaye Scholer), 'The President Has No Power Unilaterally to Abolish or Materially Change a National Monument Designation Under the Antiquities Act of 1906' (3 May 2017) 5 https://research.libraries.wsu.edu:8443/xmlui/bitstream/handle/2376/12889/ Rosenbaum\%20et\%20al.\%202017.pdf?sequence=1\&isAllowed=y accessed 4 December 2018.

203 See n 201.

204 National Parks Conservation Association, 'What Is a National Monument?' www.npca.org/resources/ 3202-what-is-a-national-monument accessed 4 December 2018.

205 Ibid.

206 'Review of Designations Under the Antiquities Act' Executive Order 13792, 82 Fed Reg 20429 (1 May 2017) www.whitehouse.gov/presidential-actions/presidential-executive-order-review-designationsantiquities-act accessed 4 December 2018.

207 Hannah Nordhaus, 'What Trump's Shrinking of National Monuments Really Means' (National Geographic, 2 February 2018) https://news.nationalgeographic.com/2017/12/trump-shrinks-bears-earsgrand-staircase-escalante-national-monuments accessed 4 December 2018.

208 Juliet Eilperin, 'Trump Orders a Review of National Monuments' Washington Post (27 April 2017) A3 www.washingtonpost.com/news/energy-environment/wp/2017/04/25/zinke-to-review-large-nationalmonuments-created-since-1996-to-make-sure-the-people-have-a-voice/?utm_term=.c604abf41970 accessed 4 December 2018.

209 'President Trump Signs Executive Order on the Antiquities Act' (27 April 2017) www.whitehouse.gov/ articles/president-trump-signs-executive-order-antiquities-act accessed 4 December 2018. 
worse and worse and worse and now we're going to free it up. It never should have happened. I am signing this order to end abuses and return control to the people. ${ }^{210}$

In the wake of the announcement, Zinke said he would consider whether any prior designations had resulted in 'loss of jobs, reduced wages and reduced public access' because 'some of these areas were put off limits for traditional uses, like farming, ranching, timber harvest, oil and gas exploration, fishing, and motorized recreation'. 211

So far only two of the 27 national monuments under review have been reduced in size: Bears Ears National Monument in Utah, which was created by President Obama in 2016, and Grand Staircase Escalante National Monument in Utah, created by President Clinton in 1996. ${ }^{212}$ President Trump reduced Bears Ears by 85 per cent, turning the 1.3 million acre national monument into a 201,397 acre monument. ${ }^{213}$ He also reduced Grand Staircase Escalante National Monument to half of its size: 1.9 million acres to 997,490 acres. $^{214}$

Trump's decision has encountered fierce opposition from some parties. Shaun Chapoose, an elected official of the Ute Indian Tribe, has said,

Bears Ears National Monument is more than just mere federal land to us, as it may be to many other stakeholders - it is a living landscape; it has a pulse. It is offensive for politicians to call the Bears Ears National Monument 'an abuse. ${ }^{215}$

As a result of the size reductions, a raft of lawsuits has been filed. Plaintiffs include American Indian Tribes, ${ }^{216}$ several environmental groups ${ }^{217}$ and Patagonia, a large outdoor recreation retail store. ${ }^{218}$ Many of these lawsuits seek injunctions to stop Trump's proclamations and orders to restore original national monument boundaries. $^{219}$ Many of the plaintiffs believe that Trump's order overstepped executive

210 Laura Parker, 'What You Need to Know About Trump's National Monument Rethink' (National Geographic, 26 April 2018) https://news.nationalgeographic.com/2017/04/trump-review-nationalmonuments-bears-ears-utah accessed 4 December 2018.

211 Juliet Eilperin, 'Trump Orders a Review of National Monuments' Washington Post (27 April 2017) A3 www.washingtonpost.com/news/energy-environment/wp/2017/04/25/zinke-to-review-large-nationalmonuments-created-since-1996-to-make-sure-the-people-have-a-voice/?utm term=.c604abf41970 accessed 4 December 2018.

212 Nordhaus (n 207).

213 Jeremy Berke, 'Trump Has Shrunk Bears Ears National Monument by 85\%, Here's What It Looks Like' (Business Insider, 25 April 2018) www.businessinsider.com/bears-ears-national-monument-pictures2017-12 accessed 4 December 2018.

214 Laura Parker, 'Leaked Maps Show How Trump May Slash National Monuments' (National Geographic, 1 December 2017) https:/news.nationalgeographic.com/2017/12/leaked-maps-trumpshrinks-bears-ears-grand-staircase-escalante-national-monuments-spd accessed 4 December 2018.

215 Eilperin (n 211).

216 See Native American Rights Fund www.narf.org/cases/protecting-bears-ears-national-monumentbears-ears accessed 4 December 2016.

217 See, eg, National Resources Defense Council www.nrdc.org/court-battles/nrdc-et-v-trump-bears-ears accessed 4 December 2018.

218 David Gelles, 'Patagonia v. Trump' (5 May 2018) www.nytimes.com/2018/05/05/business/patagoniatrump-bears-ears.html accessed 4 December 2018.

219 Courtney Tanner, 'Here's a Breakdown of the 5 Lawsuits Filed against Trump That Challenge His Cut to 2 Utah National Monuments' The Salt Lake City Tribune (11 December 2017) www.sltrib.com/news/ politics/2017/12/11/heres-a-breakdown-of-the-5-lawsuits-filed-against-trump-challenging-his-cuts-totwo-utah-national-monuments accessed 4 December 2018. 
authority. An amicus brief ${ }^{220}$ filed by more than 100 Senate and House Democrats in five lawsuits challenging the order asserted that 'the U.S. Constitution gives Congress authority over federal lands' and that 'the Antiquities Act gives the president "limited authority" to establish national monuments but not to eliminate or reduce existing ones'. 221

The consolidated challenges are now before Judge Tanya Chutkan of the US District Court for the District of Columbia, and it is possible that a court decision will be handed down early in $2019 .^{222}$

\subsubsection{US-MEXICO-CANADA TRADE DEAL}

The Trump administration in September announced completion of a new trade agreement with Canada and Mexico. ${ }^{23}$ Despite Canada's push for wording about climate change, however, none appeared in the agreement. ${ }^{224}$ In response, Mike Brune, Sierra Club Executive Director, said, 'The proposal not only fails to mention climate change - it would prolong NAFTA's contribution to the climate crisis. $^{225}$

\section{Looking ahead II: 116th US Congress}

\subsection{Introduction}

In what a major American political publication characterised as 'the most important midterm election since voters repudiated the unsteady hand of Herbert Hoover in responding to the Great Depression', ${ }^{26}$ US voters 'flipped' the US House of Representatives from Republican-controlled to Democratic-controlled, ${ }^{227}$ maintained

220 See Amicus Brief (19 November 2018) www.tomudall.senate.gov/imo/media/doc/Udall-Grijalva\% 20Wilderness\%20Society\%20Amicus\%20Brief\%20(AS\%20FILED).pdf accessed 4 December 2018. In what has been described as an 'unusual if not unprecedented legal maneuver, a Justice Department lawyer submitted a motion on [27 November 2018] to the U.S. District Court for the District of Columbia asking it to "exercise its discretion to deny" the so-called amicus briefs from the congressional delegation.' Dino Grandoni and Paulina Firozi, 'The Energy 202: Trump Administration Seeks to Block Legal Briefs from Democrats in National Monuments Case' Washington Post (30 November 2018) www.washingtonpost.com/news/powerpost/paloma/the-energy-202/2018/11/30/the-energy-202trump-administration-seeks-to-block-legal-briefs-from-democrats-in-national-monuments-case/ 5c002c6c1b326b60d128009d/?noredirect $=$ on\&utm_term=.d95e941c4999 accessed 4 December 2018.

221 Kellie Lunney, 'Democrats File Brief to Protect Utah Sites' (E\&E News, 19 November 2018) www. eenews.net/eenewspm/stories/1060106697 accessed 4 December 2018.

222 Ellen M Gilmer, 'Judge Keeps Case over Shrinking Sites in D.C.' (E\&E News, 24 September 2018) www.eenews.net/greenwire/2018/09/24/stories/1060099449 accessed 4 December 2018.

223 Everett Rosenfeld, Joanna Tan and Liz Moyer, 'Canada and US Reach Trade Deal to Replace NAFTA' (CNBC, 30 September 2018) www.cnbc.com/2018/10/01/us-canada-nafta-trade-talks.html accessed 4 December 2018.

224 Hannah Northey and Geof Koss, 'Trump Unveils Deal That's Mum on Climate' (E\&E News Greenwire, 1 October 2018) www.eenews.net/greenwire/stories/1060100209 accessed 6 October 2018.

225 Ibid.

226 Walter Shapiro, 'Opinion: Tuesday Night's Wave Came with an Undertow for the GOP' (CQ Roll Call, 7 November 2018) www.rollcall.com/news/opinion/midterm-wave-came-undertow-gop-trump accessed 4 December 2018.

227 See www.nytimes.com/interactive/2018/11/06/us/elections/results-house-elections.html accessed 4 December 2018 . 
Republican control of the US Senate, ${ }^{228}$ and awarded Democrats control of an additional seven governors' seats. ${ }^{229}$

The most consequential outcome of the election was the switch in power to the Democrats from the Republicans in the US House of Representatives. As one commentator wrote following the election, '[B]y historic measures, the House results fit the loose qualifications for a blue wave. ${ }^{230}$

Despite not winning control of the Senate, House Democrats will be able to 'complicate President Donald Trump's deregulatory efforts - by using time-honored strategies of burying agencies in oversight requests and hauling federal officials to Capitol Hill for grillings'. ${ }^{231}$ The Sierra Club's Lands Protection Program Director Athan Manuel has said, 'All the [Trump administration] agencies are so short staffed that just dealing with responding to the House will tie them up.,232

The impact of the switch of the House majority party will be addressed below.

\subsection{9-2020 Democratic-controlled US House of Representatives}

\subsubsection{INTRODUCTION}

As a result of the midterm elections, Democrats will elect the Speaker of the House and chair all House committees. This is particularly important because the House is 'controlled in large part by powerful speakers and committee chairmen'. ${ }^{233}$ Each committee chair 'has the primary agenda-setting authority for each committee and identifies which bills will receive formal committee attention during the course of the two-year Congress'. ${ }^{234}$

Consequently, for at least the next two years Democrats will 'be able to set their agendas, dictate their investigations and use their subpoena power to compel documents and haul reluctant witnesses before the panels'. ${ }^{235}$ In addition, it should be far easier for Democratic committee chairs to obtain information from the Trump administration if - and obviously this is a big qualifier - it adheres to its policy of accommodating 'the requests of chairmen, regardless of their political party'. ${ }^{236}$

228 See www.nytimes.com/interactive/2018/11/06/us/elections/results-senate-elections.html accessed 4 December 2018.

229 See www.nytimes.com/interactive/2018/11/06/us/elections/results-governor-elections.html accessed 4 December 2018.

230 Kevin M Kruse, 'Yes Mr. President, Tuesday Was a Blue Wave' Washington Post (8 November 2018) www.washingtonpost.com/outlook/2018/11/08/yes-mr-president-tuesday-was-blue-wave/?utm_term=. 0d8f23200b7a accessed 4 December 2018.

231 Jennifer A Dlouhy, 'Democrats Target Trump Environmental Rollbacks If They Win House' (Bloomberg Environment \& Energy Report, 26 October 2018) www.bloomberg.com/news/articles/2018-1026/democrats-target-trump-environmental-rollbacks-if-they-win-house accessed 4 December 2018.

232 Ibid.

233 B Guy Peters, 'The American Policy Style(s): Multiple Institutions Creating Gridlock and Opportunities' in Michael Howlett and Jale Tosun (eds), Policy Styles and Policy-Making: Exploring the Linkages (Routledge 2019).

234 Congressional Research Service, 'Introduction to the Legislative Process in the U.S. Congress' (R42843, 15 November 2018) 3 https://fas.org/sgp/crs/misc/R42843.pdf accessed 4 December 2018.

235 Jennifer A Dlouhy and Ari Natter, 'Rick Perry Won't Be Able to Hide from Gavel-Wielding Democrats' (Bloomberg Environment \& Energy Report, 9 November 2018) www.bloomberg.com/news/articles/ 2018-11-09/rick-perry-won-t-be-able-to-hide-from-gavel-wielding-democrats accessed 4 December 2018.

236 Burgess Everett and Josh Dawsey, 'White House Orders Agencies to Ignore Democrats' Oversight Requests' (Politico, 2 June 2017) www.politico.com/story/2017/06/02/federal-agencies-oversightrequests-democrats-white-house-239034 accessed 4 December 2018. 
As Democratic House Minority Leader Nancy Pelosi (D-Cal) said in the run-up to the midterm elections, 'You'll see us use every arrow in our quiver to find the truth about what's happening in public policy, [and] what [the Trump administration] is doing to the environment. 237

Environmental advocacy groups were pleased with the outcome in the House elections. Center for Biological Diversity Government Affairs Director Brett Hartl said, 'We need the new House leadership to forcefully expose and punish corruption and collusion with corporate polluters. ${ }^{238}$

\subsubsection{OVERSIGHT GENERALLY}

The Trump administration will face strenuous 'oversight', a process where 'lawmakers grill officials about alleged misdeeds' ${ }^{239}$ in relation to its environment, energy and natural resources policies. The oversight process under the Democrats will replace the first two years of the Trump presidency 'when Republicans were reluctant to aggressively question the Trump administration's handling of those issues'. ${ }^{240}$ Congressman Frank Pallone, the likely chair of the House Energy and Commerce Committee, said before the election that there is an 'endless' list of topics that a Democratically controlled House will want to examine, noting that through the Trump administration's first two years 'there's barely [been] any oversight of the EPA frankly'. ${ }^{241}$ Justin Rood, Director of the Congressional Oversight Initiative at the Project on Government Oversight, said, 'What we've seen is not only a stretch of time when you have an executive branch that has been breaking norms, but you have a Congress who's sat by without consequence and allowed that to happen without significant accountability. ${ }^{242}$

In addition to seeking explanation about Trump administration policies, hearings are also a useful way to raise the visibility of issues. Ed Whitfield, former Republican Chair of the Subcommittee on Energy and Power of the House Energy and Commerce Committee, has said, 'You know how regulations are. It's so boring, and people pay so little attention to it,' adding, 'if you have hearings and you have people testifying and you get a little news coverage, then you use those hearings back in your district., ${ }^{243}$

As a function of being the House majority party, Democratic-controlled committees will have the authority to subpoena administration officials as well as force them to

237 Scott Detrow, 'Pelosi Focuses on Retaking The House, Dismisses Questions About Her Leadership' (National Public Radio Morning Edition, 4 September 2018) www.npr.org/2018/09/04/643985147/ pelosi-focuses-on-retaking-the-house-dismisses-questions-about-her-leadership accessed 4 December 2018.

238 Stephen Lee, 'House Natural Resources Committee Pivoting to Tougher Oversight' (Bloomberg Environment \& Energy Report, 7 November 2018) https://news.bloombergenvironment.com/ environment-and-energy/house-natural-resources-committee-pivoting-to-tougher-oversight accessed 4 December 2018.

239 Peter Overby, 'Democrats Promise More Trump Investigations If They Win the House' (NPR Morning Edition, 24 October 2018) www.npr.org/2018/10/24/660112922/democrats-promise-more-trumpinvestigations-if-they-win-the-house accessed 4 December 2018.

240 Dlouhy and Natter (n 235).

241 Robin Bravender and Geof Koss, 'Dems Prepare "Flood" of Energy, Climate Investigations' (E\&E Daily, 6 September 2018) www.eenews.net/stories/1060095957 accessed 4 December 2018.

242 Overby (n 239).

243 Kevin Bogardus, “We Obviously Are Suspicious” - Dems Prep for 2019' (E\&E News Greenwire, 31 October 2018) www.eenews.net/stories/1060104813 accessed 4 December 2018. 
produce documents. This is by no means an insignificant power since 'dogged House Democratic oversight could make [Trump administration] jobs less appealing for [presidential] nominees'. ${ }^{244}$ However, it may not be as effective a tool to force administration disclosure as one might think. Director Austin Evers of American Oversight, a non-profit, non-partisan organisation that investigates the Trump administration, has said, 'It's actually very difficult to enforce a congressional subpoena in court. In contrast, a Freedom of Information Act request [allows American Oversight] to go to court very easily and force agencies to be transparent. 245

The process of conducting oversight hearings will have an impact on the Trump administration some say. An important Trump supporter, Tom Pyle, President of the American Energy Alliance, said before the election that a Democratic win in the House would allow Democrats to 'tie up [Trump administration] agencies mercilessly so that they would kind of be able to slow walk a lot of the good work that's being done on these issues'. ${ }^{246}$ However, George David Banks, a former adviser to Trump, is less certain about any potential impact. 'I don't see much of a change in the regulatory space,' Banks said. 'Obviously, the House can influence it to a certain degree through oversight' although 'I'm not even sure how much oversight really impacts the executive branch. Certainly the Obama administration's regulatory agenda was not curtailed by the Republican Congress.' 247

Finally, a former Democratic US Senator Carl Levin (D-Mich) has sounded a cautionary note about the oversight role for the newly empowered House Democrats. 'If oversight is going to effect change,' Levin said, 'including changing policy, it's got to be bipartisan. It's a fact of life.'248

\subsubsection{Climate Change}

Addressing the challenge of climate change will be among the top priorities of the Democratic House. Congressman Frank Pallone (D-NJ), the likely chair of the powerful House Energy and Commerce Committee and described in a New York Times editorial as 'far more concerned about climate change than any of the Republicans [on the committee]', ${ }^{249}$ has said that a high priority will be 'to try and do what we can to address climate change' ${ }^{250}$ In response to the dire warnings of the National Climate Assessment, published on 23 November 2018, Pallone said, 'The days of denial and inaction in the House are over as House Democrats plan to aggressively address

244 Corbin Hiar, 'Trump Could "Flood the Zone" to Combat House Democrats' (E\&E Greenwire, 15 November 2018) www.eenews.net/stories/1060106349 accessed 4 December 2018.

245 Overby (n 239).

246 Nathan Rott, "After Midterms, Democrats Hope to "Change the Narrative" on Environmental Rollbacks' (National Public Radio, 16 October 2018) www.npr.org/2018/10/16/657523536/aftermidterms-democrats-hope-to-change-the-narrative-on-environmental-rollbacks accessed 4 December 2018.

247 Hiar (n 244).

248 Corbin Hiar, 'Oversight Has "Got to Be Bipartisan" - Former Senator' (E\&E News, 16 November 2018) www.eenews.net/special_reports/2018_midterms_powershift/stories/1060106521 accessed 4 December 2018.

249 Editorial, 'Midterm Climate Report: Partly Cloudy' New York Times (9 November 2018) www.nytimes. com/2018/11/09/opinion/climate-change-midterm-elections.html accessed 4 December 2018.

250 Bravender and Koss (n 241). 
climate change and hold the Administration accountable for its backward policies that only make it worse. 251

However, it is not clear whether the House Democrats have a specific legislative strategy for addressing climate change.

The party's efforts as currently planned won't be enough to spur the rapid transformation in how society operates that leading scientists say is needed to spare humanity from the worst of rising temperatures, extreme weather and massive societal and economic disruptions,

it has been suggested. ${ }^{252}$ Congressman John Delaney (D-Maryland), who has already announced plans to run for the Democratic nomination for President in 2020, has said,

Obviously, a transformative government response to climate change is clearly needed based on what we're seeing from science. We have about 10 years left to really be doing something, but it's hard [for Democrats] to do because the Republican Party is largely in denial on this. ${ }^{253}$

The internal pressure on Democrats to take action is palpable. One senior Democrat Congresswoman, Diana DeGette (D-Colorado), has plans to introduce legislation mandating greenhouse gases cap-and-trade programmes. ${ }^{254}$ And newly elected Congresswomen Alexandria Oscasio-Cortez (D-NY) has tweeted, 'People are going to die if we don't start addressing climate change [as soon as possible]. It's not enough to think it's "important." We must make it urgent.,255

If Democrats fail or choose not to pass major climate change-related legislation, then another approach may be to support infrastructure projects 'to prepare communities for climate change and [investment in] green power', according to one knowledgeable Democratic aide. ${ }^{256}$

Notwithstanding the apparent widespread support among Democrats to address climate change in some manner, it has been suggested that House leaders must think strategically. Progressive Party Institute Fellow Paul Bledsoe, a Clinton administration climate adviser, has cautioned, 'Impossible-to-reach targets will only disappoint.' 257

251 Matt Daily, 'Trump's Dire Climate Report Hands Ammunition to Democrats' (Politico, 23 November 2018) www.politico.com/story/2018/11/23/us-climate-report-warns-of-dire-changes-by-2050-1012628 accessed 4 December 2018.

252 Emily Holden, “Precious Little": Democrats Lack Robust Climate Change Plan Despite Global Crisis' The Guardian (London, 1 November 2018) www.theguardian.com/environment/2018/oct/31/climatechange-democrats-house-midterms-pollution-plan accessed 4 December 2018.

253 Ibid.

254 Jean Chemnick, 'Dem Leadership Preps for Climate Issues to Take Center Stage' (E\&E Climatewire, 9 November 2018) www.eenews.net/climatewire/2018/11/09/stories/1060105779 accessed 4 December 2018.

255 Alexandria Ocasio-Cortez twitter feed (23 November 2018) https://twitter.com/Ocasio2018?ref src= twsrc\%5Egoogle\%7Ctwcamp\%5Eserp\%7Ctwgr\%5Eauthor accessed 2 December 2018.

256 Holden (n 252).

257 Hannah Northey, 'What Exactly Is the "Green New Deal"?' (E\&E Greenwire, 16 November 2018) www.eenews.net/stories/1060106501 accessed 4 December 2018. 
Finally, there may potentially be a political issue for Democratic efforts about climate change. In an effort to no doubt fill their campaign 'coffers', the Democratic National Committee earlier this year 'dropped its ban on fossil fuel-industry campaign contributions... [thus potentially] clogging the political path to ... climate-related reforms with yet more energy-industry dollars'. ${ }^{258}$

\subsubsection{A 'Green New DeAL'?}

In the wake of the midterm results, House leaders were being asked - in some cases very publicly ${ }^{259}$ - to embrace a 'Green New Deal' (GND), an energy-environmenteconomic package inspired by the original New Deal proposed by President Franklin D Roosevelt in the 1930s to address the economic depression. The concept of a GND was originally proposed by the Sunrise Movement, a group aiming to build 'an army of young people to make climate change an urgent priority across America'. ${ }^{260}$ Sunrise is advocating that House Democrats establish a GND select committee, which would draft a '10-year green jobs and infrastructure plan to radically reduce carbon emissions with expanding living-wage jobs'. ${ }^{261}$

Draft text for the establishment of the GND select committee provides in part, 'The select committee shall have authority to develop a detailed national, industrial, economic mobilization plan ... for the transition of the United States economy to become carbon neutral and to significantly draw down and capture greenhouse gases from the atmosphere and oceans. ${ }^{262}$

The GND has been described as a 'giant policy bucket that includes "clean tech" job incentives and credits, energy-system overhaul, massive expansion of renewable energy, green urban public works, agroforestry and more'. ${ }^{263}$

The GND proposal envisions that the select committee would publish a draft plan by 1 January 2020, and by 1 March 2020, finalise legislative elements. ${ }^{264}$ Adhering to this timeframe would consequently allow Democrats to move quickly ahead in the event they 'regain power in 2021 and beyond', according to proposal supporters. ${ }^{265}$

\subsubsection{A CARBON TAX?}

Many political observers consider the imposition of a carbon tax as the best way to reduce carbon emissions. ${ }^{266}$ However, there is also a recognition that 'carbon

258 Christopher D Cook, 'Can the Blue Wave Deliver a Green New Deal?' (The Nation, 20 November 2018) www.thenation.com/article/can-the-blue-wave-deliver-a-green-new-deal accessed 4 December 2018.

259 Congresswoman Alexandria Ocasio-Cortez (D-NY) led a group of protestors to Congresswoman Nancy Pelosi's (D-Cal) office in November 2018. Nick Sobczyk and Nick Bowlin, 'Sunrise Storms District Offices, Collects Endorsements' (E\&E Greenwire, 21 November 2018) www.eenews.net/ greenwire/stories/1060107225 accessed 4 December 2018.

260 See www.sunrisemovement.org accessed 4 December 2018.

261 Cook (n 258).

262 Alexandria Ocasio-Cortez for Congress campaign website https://ocasio2018.com/green-new-deal accessed 4 December 2018.

263 Cook (n 258).

264 Northey (n 257).

265 Ibid.

266 See, eg, 'Democrats and a Climate-Change Dilemma' The Economist (24 November 2018) www.economist. com/united-states/2018/11/24/democrats-and-a-climate-change-dilemma accessed 4 December 2018. 
taxes are easily denounced as energy taxes, which voters do not much appreciate'. ${ }^{267}$ Nevertheless, some advocates of addressing climate change are preparing carbon tax proposals in the hopes of attracting the support of House Democrats. The Climate Leadership Council (CLC), which includes such luminaries as former Federal Reserve Bank Chair Janet Yellen and former EPA Administrator Christine Todd Whitman as well as some of the world's largest oil and gas companies, ${ }^{268}$ is one such group. In 2019, the CLC intends to release 'a detailed carbon tax proposal that lawmakers could turn into a federal bill' ${ }^{269}$ The proposal 'would slap an initial $\$ 40$ per ton tax on carbon emissions that would steadily increase over time. In doing so, US industry would have an economic incentive to reduce its carbon footprint. ${ }^{270}$ However, the CLC acknowledges that members of both parties must support the tax in order to win congressional approval. CLC spokesperson Greg Bertelsen has said, 'Members who are interested in finding a serious solution understand that this will have to be bipartisan.' 271

Despite the challenges that may lie ahead for a carbon tax proposal, one former member of the House tax-writing committee, Sander Levin (D-Mich), has suggested, 'I think for the first time in years, once the Democrats take over the House, there will be serious consideration of [a carbon tax] at long last. ${ }^{, 272}$ However, two fundamental complications will be whether such legislation can get through the Republican-controlled Senate - much less be signed by Trump. ${ }^{273}$ Moreover, a House effort to pass a carbon tax may be 'a self-defeating political strategy and a self-defeating climate strategy' because it could put in peril the Democratic control of the House in the November 2020 election, according to former Clinton administration climate adviser Paul Bledsoe. ${ }^{274}$ Perhaps a better strategy might be to propose legislation that combines tax credits for development of nuclear and wind energy technologies with a carbon tax. $^{275}$ This might attract votes from Republican congressional members whose districts include wind or nuclear installations, according to Professor Matthew Nisbet of Northeastern University. ${ }^{276}$

Interestingly enough, at the end of November 2018, one Democratic congressman, Ted Deutch (Fla), and two Republican congressmen, Brian Fitzpatrick (Pa) and Francis Rooney (Fla), introduced the first bipartisan legislation in a decade to address climate change. $^{277}$ The legislation would have set a $\$ 15$ per metric ton of carbon emissions fee

267 Ibid.

268 See www.clcouncil.org/founding-members accessed 4 December 2018.

269 Mark Matthews, 'Want a Carbon Tax? Wait Until Next Year, Top Advocates Say' (E\&E News Climatewire, 11 September 2018) www.eenews.net/climatewire/2018/09/11/stories/1060096477 accessed 4 December 2018.

270 Ibid.

271 Ibid.

272 Nick Sobczyk, 'Dems See Tax Panel as a Venue for Energy, Climate Policy' (E\&E News Daily, 19 September 2018) www.eenews.net/stories/1060098299/print accessed 4 December 2018.

273 Ibid.

274 'Democrats and a Climate-Change Dilemma' (n 266).

275 Ibid.

276 Ibid.

277 HR 7173 Energy Innovation and Carbon Dividend Act of 2018 www.congress.gov/bill/115th-congress/ house-bill $/ 7173$ ?q= $\% 7 \mathrm{~B} \% 22$ search $\% 22 \% 3 \mathrm{~A} \% 5 \mathrm{~B} \% 22$ climate \pm change $\% 22 \% 5 \mathrm{D} \% 7 \mathrm{D} \& \mathrm{r}=1$ accessed 4 December 2018. 
on the coal, gas and oil industries, and would have rebated all of it in the form of household dividends. ${ }^{278}$ Introduction of the legislation was intended 'to plant a flag for climate change efforts' in the congressional session that begins in January $2019 .{ }^{279}$ Ironically, the Republican congressman most supportive of a carbon tax, Carlos Curbelo of Florida, was defeated in the midterm election. ${ }^{280}$ And in any case, the virulently anti-tax group, Americans for Tax Reform, came out against the bill, referring to it as 'a tax on your electric bill'. ${ }^{281}$

\subsubsection{Key House committees}

\subsubsection{Introduction}

A great deal of the work of the House of Representatives takes place within its standing committees. These committees 'gather information; compare and evaluate legislative alternatives; identify policy problems and propose solutions; select, determine, and report measures for full [House] consideration; monitor executive branch performance (oversight); and investigate allegations of wrongdoing'. ${ }^{282}$

What follows is a list of the key House committees and the probable focus of each committee with respect to energy, environment and natural resources matters.

\subsubsection{Energy and commerce}

Under Democratic leadership the focus of the committee is likely to switch from energy, as it was under the Republicans, to more environmental-related matters. ${ }^{283}$ New Jersey Congressman Frank Pallone, the likely committee chair, will emphasise renewable energy as well as re-establishing 'environmental protection gutted over the last two years' ${ }^{284}$ The Trump administration's 'fixation on reviving the coal industry' is also likely to run afoul of Pallone's leadership. ${ }^{285}$ In particular, Department of Energy Secretary Rick Perry will receive increasing scrutiny from the committee, particularly as it involves the 'agency's unsuccessful proposal to boost coal and nuclear plants in the name of energy security'. ${ }^{286}$ And Pallone is expected to investigate Perry's relationship with Bob Murray, a coal executive who met with the secretary in 2017 and presented 'a

278 Dean Scott, 'Bipartisan Climate Fee Backers to Plant Flag during Lame Duck' (Bloomberg Environment \& Energy Report, 26 November 2018) www.bna.com/bipartisan-climate-fee-n57982094127 accessed 4 December 2018.

279 Ibid.

280 Lisa Friedman, 'Climate Fwd: What the Midterms Mean for Climate Change' New York Times (7 November 2018) www.nytimes.com/2018/11/07/climate/climate-fwd-midterms.html accessed 4 December 2018.

281 Nick Sobczyk, 'Carbon Bill Boosters See Fertile Ground in New Congress' (E\&E Greenwire, 28 November 2018) www.eenews.net/special_reports/2018_midterms_powershift/stories/1060107595 accessed 4 December 2018.

282 Congressional Research Service, 'Committee Types and Roles' (98-241, 2 May 2017) 2 https://fas.org/ sgp/crs/misc/98-241.pdf accessed 4 December 2018.

283 George Cahlink, 'Energy and Commerce Committee to Focus on Green Issues If Dems Take Over' (E\&E News Daily, 6 November 2018) www.eenews.net/special_reports/2018_midterms_powershift/ stories/1060105249 accessed 4 December 2018.

284 Dlouhy and Natter (n 235).

285 Hannah Northey and Christa Marshall, 'Perry Loves His Job. That Could Change' (E\&E News, 1 November 2018) www.eenews.net/stories/1060104913 accessed 4 December 2018.

286 Ibid. 
dozen draft executive orders aimed at exiting the Paris climate accord and peeling back coal regulations'. 287

Climate change-related matters will also get more committee attention. For example, committee member Rep Kathy Castor (D-Fla) has said, 'People understand the changing climate, the cost of the changing climate, and I think the committee is going to have a new focus on what we can do to decarbonize the atmosphere. ${ }^{288}$ Another committee member, Congressman Paul Tonko (D-NY), has called for promoting electric car charging stations and modernising the energy grid. ${ }^{289}$ Tonko also 'plans to offer a set of principles for climate action early in the new Congress'. ${ }^{290}$

Congressmen Pallone (NJ) and Tonko (NY) and Congresswoman DeGette (CO) underscored their concern about efforts to diminish federal efforts to address carbon emissions in a late November 2018 letter to EPA Acting Administrator Andrew Wheeler.

We write to express our deep concerns about actions taken by the Environmental Protection Agency (EPA) to roll back policies to reduce greenhouse gas emissions and address our changing climate. The tragic human and financial costs of unchecked climate change are high and increasing fast, and unfortunately the Administration's actions for the last two years are only exacerbating these conditions. ${ }^{291}$

The three representatives went on to write, 'We are requesting EPA provide us information that will help us understand how these decisions were made and how these actions will affect the environmental and human health. ${ }^{292}$ In particular, the representative requested more detailed information about the ACE, SAFE and Methane Replacement rules. $^{293}$

\subsubsection{Science, space and technology}

Likely committee chair Congresswoman Eddie Bernice Johnson (D-Texas) has vowed to 'restore the credibility' of the committee which, for six years, was used by former chair Congressman Lamar Smith (R-Texas), who has retired, 'to cast doubt on mainstream climate science', according to one observer. ${ }^{294}$ Congresswoman Johnson, who likes to call the panel the 'Committee of the Future', has said one of the committee's top priorities will include addressing 'the challenge of climate change, starting with acknowledging it is real, seeking to understand what climate science is telling us, and working to understand the way we can mitigate it'. ${ }^{295}$ Among the

287 Ibid.

288 Cahlink (n 283).

289 Ibid.

290 Jean Chemnick, 'Dem Leadership Preps for Climate Issues to Take Center Stage' (E\&E Climatewire, 9 November 2018) www.eenews.net/climatewire/2018/11/09/stories/1060105779 accessed 4 December 2018.

291 Frank Pallone Jr, Diana DeGette and Paul D Tonko, 'Letter to EPA Administrator Andrew Wheeler' (20 November 2018) copy of original with authors.

292 Ibid.

293 Ibid.

294 Dlouhy and Natter (n 235).

295 Eddie Bernice Johnson, 'Congresswoman Johnson Announces Intention to Seek Chairmanship of Science Committee' https:/ebjohnson.house.gov/media-center/press-releases/congresswomanjohnson-announces-intention-to-seek-chairmanship-of accessed 4 December 2018. 
issues Congresswoman Johnson expects to consider are reducing greenhouse gas emissions, exploring technology 'such as geoengineering and carbon capture and sequestration', and working on mitigation and adaptation strategies. ${ }^{296}$

She has also said the committee should be 'a place where science is respected and recognized as a crucial input to good policymaking'. ${ }^{297}$

During the 2017-2018 congressional session, Congresswoman Johnson, joined by more than 150 House Democrats, ${ }^{298}$ co-sponsored the Scientific Integrity Act, ${ }^{299}$ 'which would require federal science agencies to develop policies that guarantee research is published and conducted without censorship or political influence'. ${ }^{300}$

\subsubsection{Natural resources}

The committee's likely chair, Congressman Raul Grijalva (D-NM), has been described as the 'polar opposite' of former Republican chair Rob Bishop (Utah), who was 'one of President Trump's main allies in the effort to rescind national monument designations as well as open up public lands for extractive industries'.301

In addition to wanting an explanation about 'what went into recommending a reduction in Utah's Bears Ears National Monument', he will also probably 'press for more renewable energy production on federal lands and for climate change to be incorporated into federal decisions on natural resources'. ${ }^{302}$

Two legislative measures that are likely to be pursued by Congressman Grijalva are: (1) to secure 'permanent authorization for the Land and Water Conservation Fund, the 1965 law that sets aside money for national parks, wildlife refuges, forests, and recreation areas'; and (2) to revise the Mining Law of 1972 by setting a ' 12.5 percent royalty on new mines and an 8 percent royalty on existing mines' to generate funding for cleaning up abandoned mines. ${ }^{303}$

The committee is also expected to investigate 'what prompted National Park Service officials to delete references to humans' role in driving climate change from a scientific report on rising seas, ${ }^{304}$

296 Scott Waldman, 'White House Plays Down Climate Report's Alarming Findings' (E\&E Climatewire, 26 November 2018) www.eenews.net/stories/1060107253 accessed 4 December 2018.

297 Johnson (n 295).

298 Christa Marshall, George Cahlink and Sean Reilly, '5 Things to Watch on Science Panel Next Year' (E\&E News Daily, 12 October 2018) www.eenews.net/eedaily/stories/1060102393 accessed 4 December 2018.

299 See HR 1358 - Scientific Integrity Act www.congress.gov/bill/115th-congress/house-bill/1358 accessed 4 December 2018.

300 Marshall, Cahlink and Reilly (n 298).

301 Editorial (n 249).

302 Alan Kovski, 'Grijalva Looks for More Oversight If Democrats Win House' (Bloomberg Environment \& Energy Report, 5 October 2018) www.bna.com/grijalva-looks-oversight-n73014483057 accessed 4 December 2018.

303 Stephen Lee, 'House Natural Resources Committee Pivoting to Tougher Oversight' (Bloomberg Environment \& Energy Report, 7 November 2018) https://news.bloombergenvironment.com/ environment-and-energy/house-natural-resources-committee-pivoting-to-tougher-oversight accessed 4 December 2018

304 Dlouhy and Natter (n 235). 


\subsubsection{Ways and means}

The importance of this committee is related to its role as the chief tax-writing panel for the House. ${ }^{305}$ Long-time committee member Congressman Earl Blumenauer (DOregon), and several other Democrats, are reportedly eager to 'push a carbon tax as a solution for climate change'. He has expressed hope for 'a balanced hearing - hear from people in the business community, hear from people that are state and local, hear from environmentalists, hear from scientists for heaven's sake'. ${ }^{306}$ However, senior committee member Congressman John Lewis (D-Georgia) has observed that despite the interest in putting a price on carbon emissions, the House Democratic leadership may not 'want to get ahead of itself on the issue'. 307

\section{Conclusion: where is the US heading?}

President Trump's first two years in office have been marked by the administration's 'disregard for scientific evidence' involving climate change in particular. $^{308}$ Instead he

has made the dismantling of policies to curb greenhouse gas pollution a centerpiece of his deregulatory agenda. The most direct way the Trump administration is working to allow more greenhouse gas emissions is by weakening the Obama-era regulations meant to reduce pollution at its source: the smokestacks of power plants and tailpipes of automobiles. ${ }^{309}$

However, Democratic control of the House 'promises to roil the final two years' of Trump's first term in office. ${ }^{310}$ That said, perhaps the most used term in 2019-2020 among House Democrats will be 'oversight' because 'nearly all of the rollbacks in environmental [and energy] policy are happening [through regulatory changes] in the executive branch under Trump appointees. A shift in House leadership won't change that., ${ }^{311}$

The day after the midterm election, Trump said the two parties had to work together on various issues including protecting the environment. 'We want crystal-clean water. We want beautiful, perfect air. Air and water, it has to be perfect,' he said. ${ }^{312}$ However, in this next sentence, Trump indicated his unwillingness to take any action that might harm, in his view, the economy:

[W]e don't want to put ourselves at a disadvantage to other countries who are very competitive with us and who don't abide by the rules at all. We don't want to hurt our jobs. We don't want to hurt our factories. We don't want companies leaving. ${ }^{313}$

305 See https://waysandmeans.house.gov/about accessed 4 December 2018.

306 Nick Sobczyk, 'Dems See Tax Panel as a Venue for Energy, Climate Policy' (E\&E News Daily, 19 September 2018) www.eenews.net/stories/1060098299 accessed 4 December 2018.

307 Ibid.

308 Davenport and Friedman (n 49).

309 Ibid.

310 Matthews (n 40).

311 Rott (n 246).

312 Scott Waldman, 'Trump Ignored His Notes to Talk about the Environment' (E\&E News, 14 November 2018) www.eenews.net/climatewire/2018/11/14/stories/1060106175 accessed 4 December 2018.

313 Ibid. 
And Trump's allies 'hope his administration will plow ahead with its deregulatory energy and environment agenda next year, despite resistance from newly empowered House Democrats'. 314

It is entirely likely that the House Energy and Commerce committee will be the first to subject the Trump policies to severe oversight, bearing in mind the detailed letter sent by three senior Democratic members of the panel to the EPA. ${ }^{315}$ And the chairs of the Energy and Commerce, Natural Resources, and Science and Technology committees will be holding a series of hearings focused on climate science in early 2019..$^{316}$

Perhaps Colorado Democratic Senator Michael Bennet captured the reality of the fraught issues around climate change in particular when he said in late November 2018, 'Rather than politicizing science and cherry-picking [the National Climate Assessment report's] findings, we need a serious, bipartisan strategy to address our changing climate. And we need the president's leadership. ${ }^{317}$ Senator Bennet's call for bipartisan efforts was also echoed by Republican Senators Susan Collins of Maine $^{318}$ and Thom Tillis of North Carolina. ${ }^{319}$ Departing Republican Congressman Carlos Curbelo from Florida agrees. Bipartisan approaches are the key, rather than Democrats acting alone, he has said. ${ }^{320}$

Finally, irrespective of the political wrangling in Washington over climate change, nearly three-quarters of Americans surveyed recently think 'solid evidence' exists that the globe is warming, according to new data from the University of Michigan and Muhlenberg College. ${ }^{321}$ Strikingly, the same survey indicated that

while President Trump's recent statements indicate his uncertainty about the quality of evidence regarding climate change, a majority (52\%) of his fellow Republicans during the fall of 2018 stated that they believe there is solid evidence of global warming over the past four decades. ${ }^{322}$

Meanwhile, from an international perspective, the Trump administration's decision to withdraw from the Paris Agreement may also have serious ramifications. 'When the U.S. is not taking action on climate it makes it incredibly difficult for countries with lesser means than ours to take action themselves,' the President of the non-partisan thinktank Resources for the Future Richard G Newell has said. ${ }^{323}$ For example, Jair

314 Hiar (n 244).

315 Pallone, DeGette and Tonko (n 291).

316 Abby Smith, 'Climate Report Could Bolster Local Efforts, Given Federal Inaction (1)' (Bloomberg Environment \& Energy Report, 23 November 2018) www.bna.com/climate-report-bolstern57982094119 accessed 4 December 2018.

317 Michael Bennet, 'Congress Needs Bipartisan Strategy as Trump Doubles Down against Climate Science' The Colorado Sun (26 November 2018) https://coloradosun.com/2018/11/26/michaelbennet-opinion-climate-change accessed 4 December 2018.

318 https://twitter.com/SenatorCollins/status/1067067646477246464 accessed 4 December 2018.

$319 \mathrm{https} / /$ twitter.com/senthomtillis/status/1067182080390561792 accessed 4 December 2018.

320 Nick Sobszyk, 'Carlos Curbelo Doesn't Care What You Think' (E\&E News Daily, 29 November 2018) www.eenews.net/stories/1060108149 accessed 4 December 2018.

321 Center for Local, State, and Urban Policy at the University of Michigan, 'Findings from the Fall 2018 National Surveys on Energy and Environment' (fall 2018) http://closup.umich.edu/national-surveyson-energy-and-environment/nsee-2018-fall/beliefs.php accessed 4 December 2018.

322 Ibid.

323 Davenport and Friedman (n 49). 
Bolsonaro, President-elect of Brazil, has vowed to leave the Paris Agreement. ${ }^{324}$ Moreover, rich countries, as well, may not be immune from Trump's actions. Prime Minister Scott Morrison of Australia has warned about pulling out of the agreement. ${ }^{325}$ 